University of Louisville

ThinkIR: The University of Louisville's Institutional Repository

Electronic Theses and Dissertations

1933

\title{
The organic acid content of normal and pathological blood by the use of the quinhydrone electrode.
}

Letitia Green

University of Louisville

Follow this and additional works at: https://ir.library.louisville.edu/etd

Part of the Biochemistry, Biophysics, and Structural Biology Commons

\section{Recommended Citation}

Green, Letitia, "The organic acid content of normal and pathological blood by the use of the quinhydrone electrode." (1933). Electronic Theses and Dissertations. Paper 2037.

https://doi.org/10.18297/etd/2037

This Master's Thesis is brought to you for free and open access by ThinkIR: The University of Louisville's Institutional Repository. It has been accepted for inclusion in Electronic Theses and Dissertations by an authorized administrator of ThinkIR: The University of Louisville's Institutional Repository. This title appears here courtesy of the author, who has retained all other copyrights. For more information, please contact thinkir@louisville.edu. 


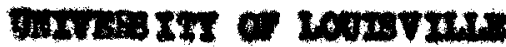

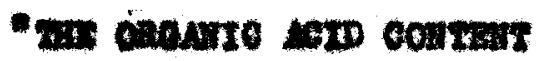

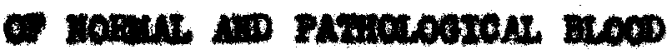 \\ Ix $\operatorname{mes}$ or

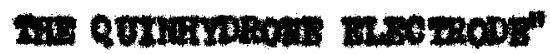

\author{
4 Btivertiation \\ stablend to the Feoulty

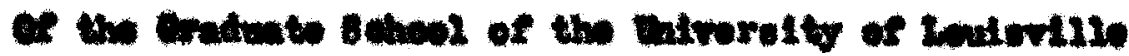

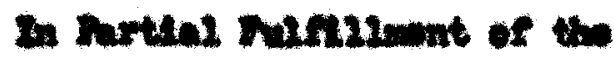 \\ Dequidrmonte for the Dopore \\ a runter actone

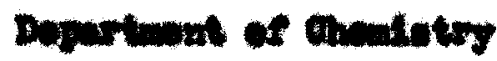 \\ ty \\ 2outere conem
}

108 


\section{UHE UNWvessir LIBRARIES}

This PDF document is a scanned copy of a paper manuscript housed in the University of Louisville (UofL) Libraries. The quality of this reproduction is greatly dependent upon the condition of the original paper copy. Indistinct print and poor quality illustrations are a direct reflection of the quality of materials that are available for scanning. The UofL Libraries greatly appreciates any better copies that can be made available for replacement scans. 
2ase or conters

\section{Ding}

Detertanl

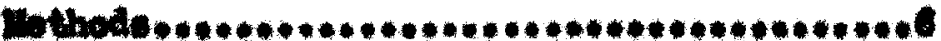
Imprimatel

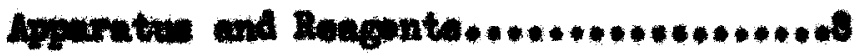

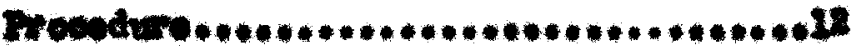

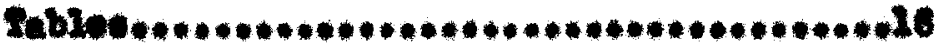

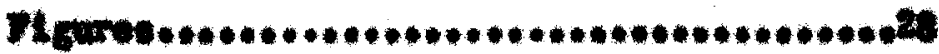

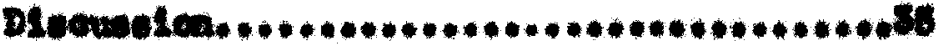

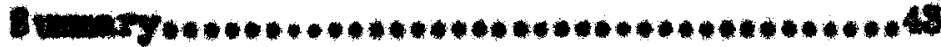

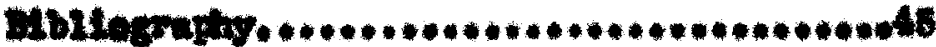
Aramiedrimat 
Es xarod. 


\section{Exarant.}

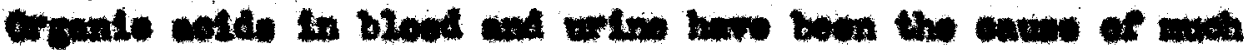

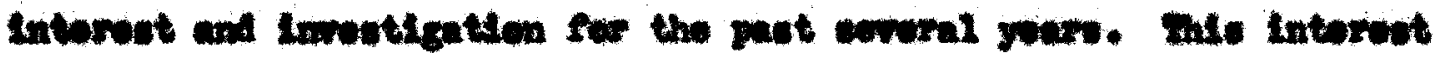

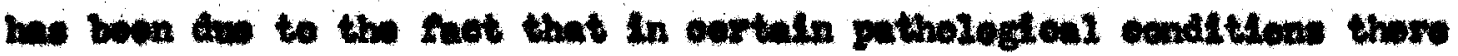

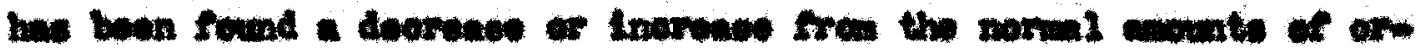

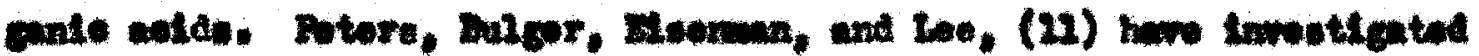

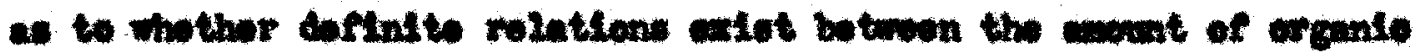

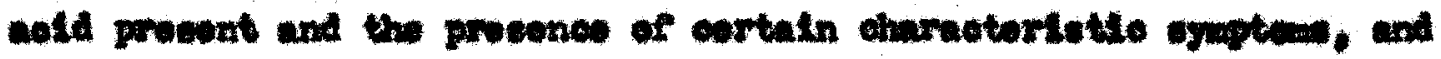

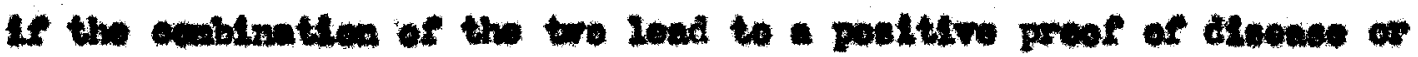

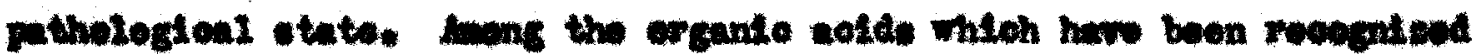

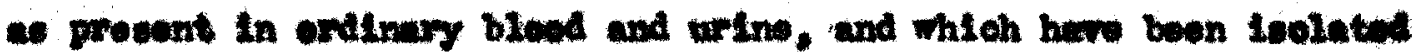

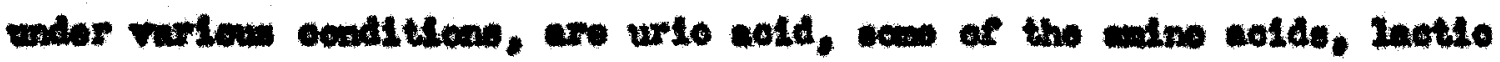

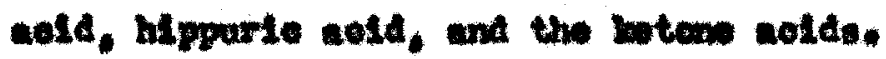

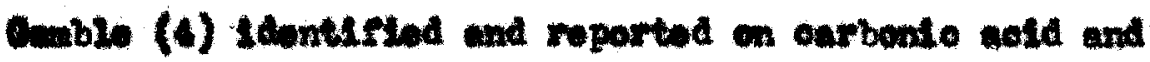

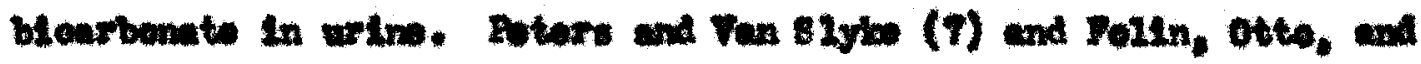

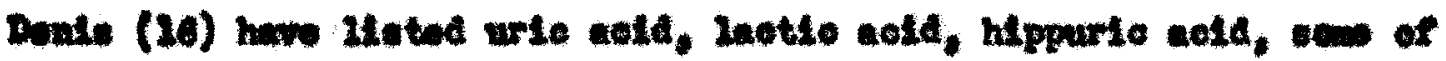

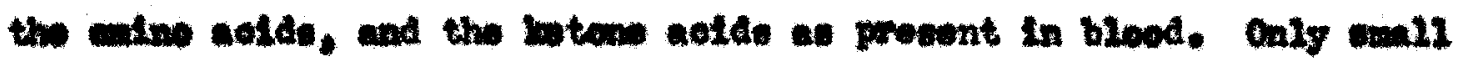

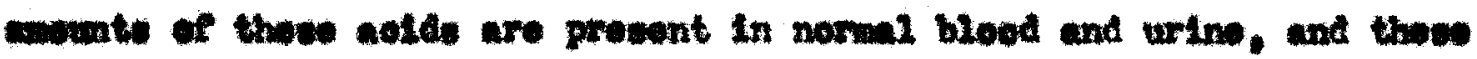

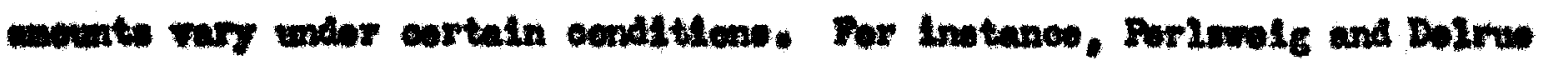

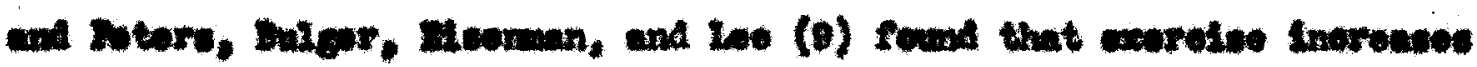

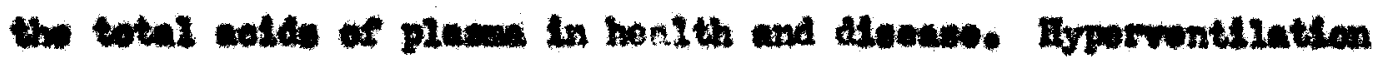

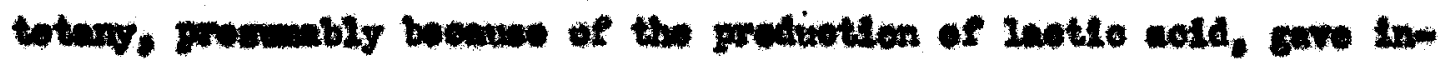

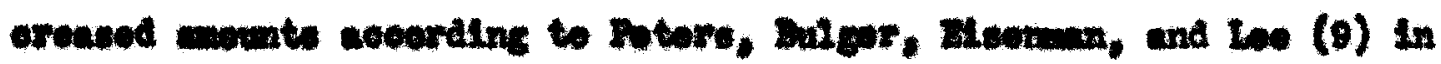

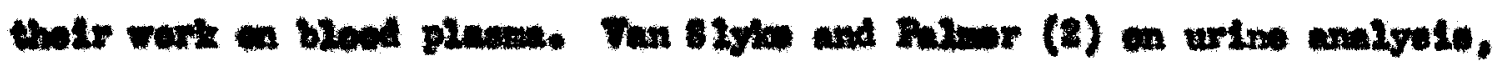

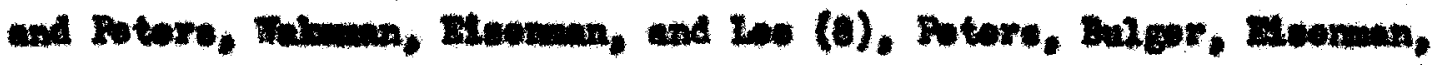




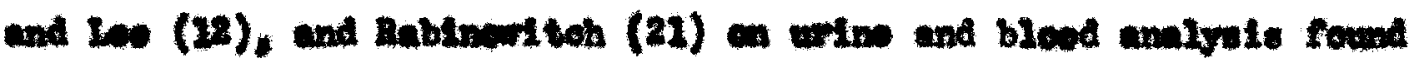

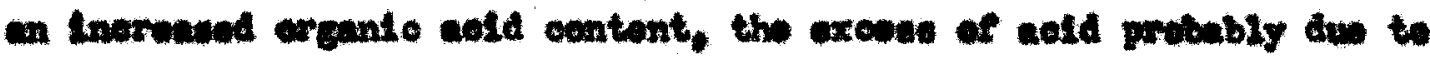

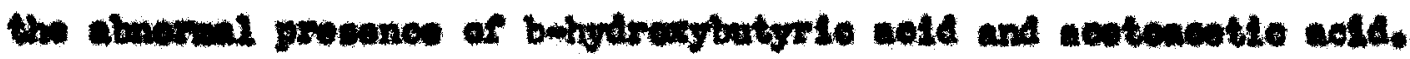

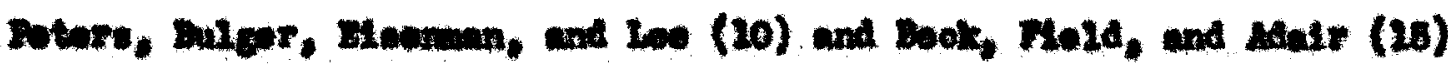

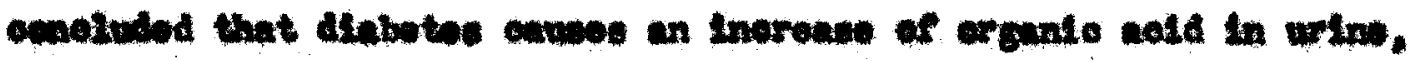

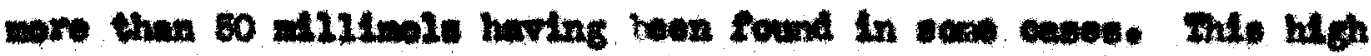

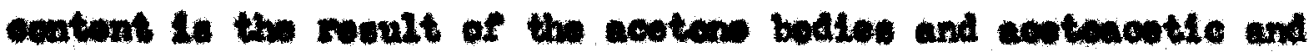

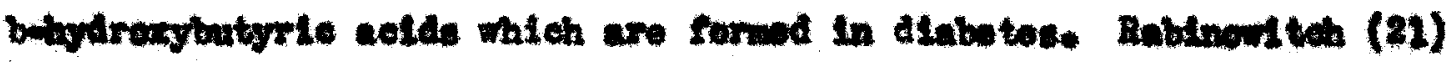

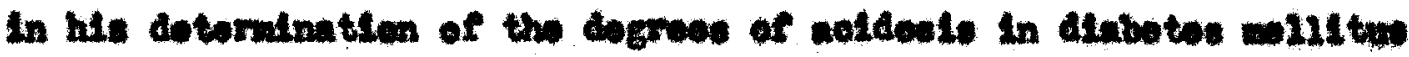

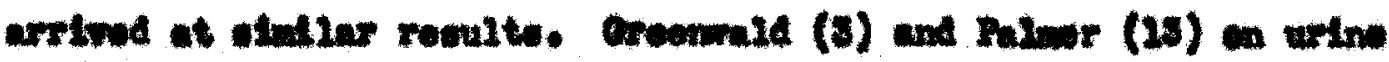

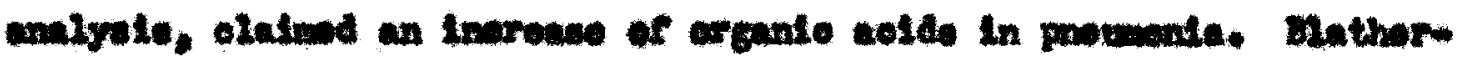

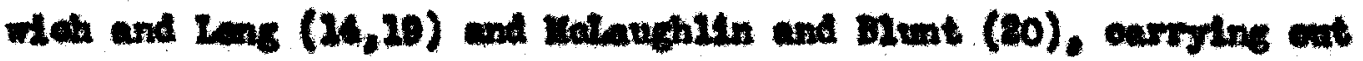

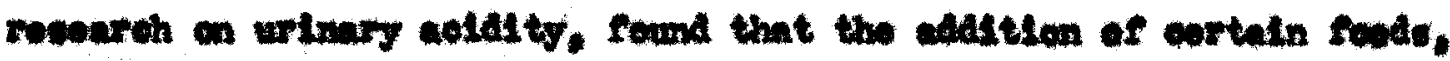

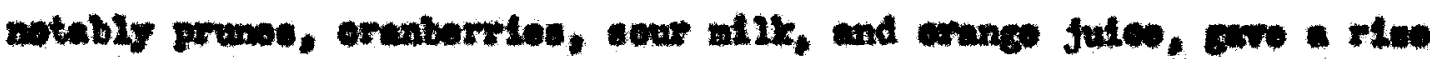

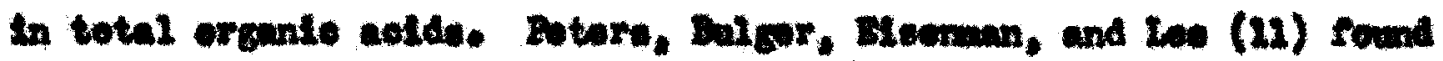

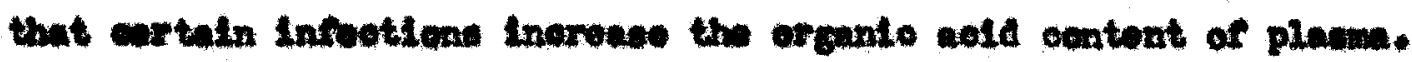

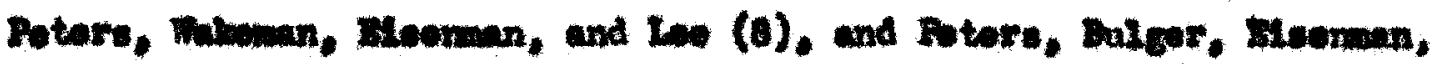

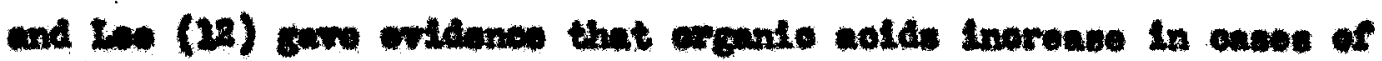

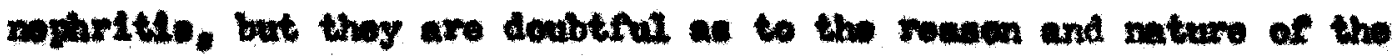

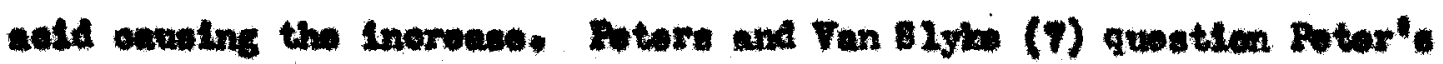

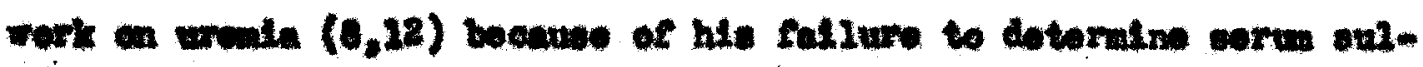

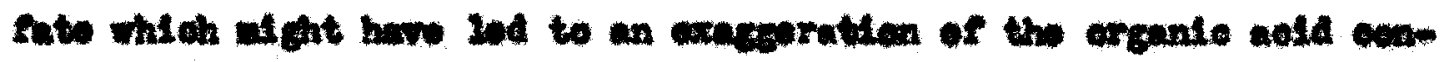

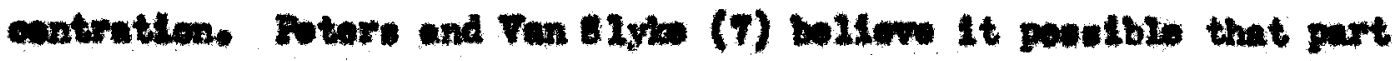

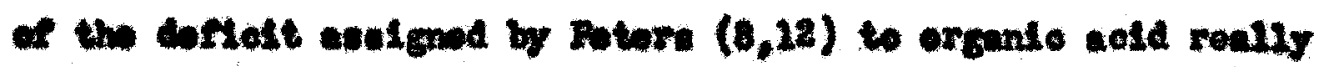
ruprosente base cemblned with Inorganlo oulfer.

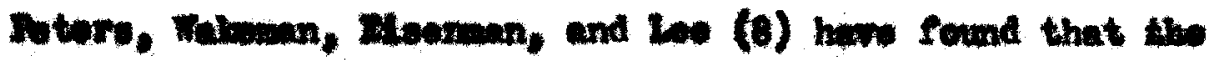

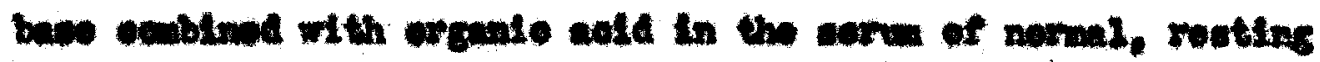




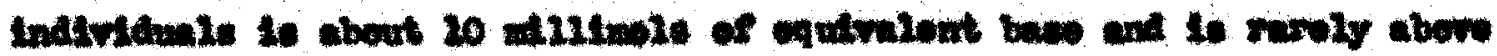

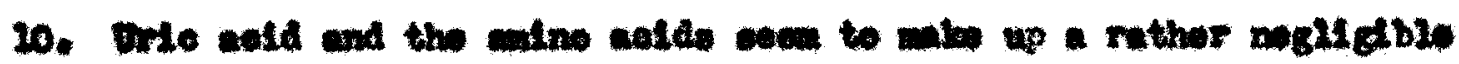
part of this total. Portionis and Dolwe (1) townd in nowel, blow,

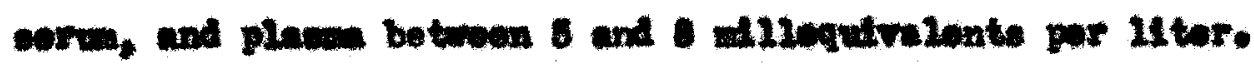

It Is the objoet of this papar to ouledt to trial the wothed

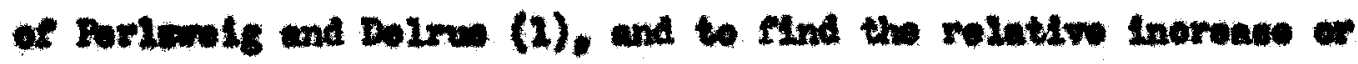

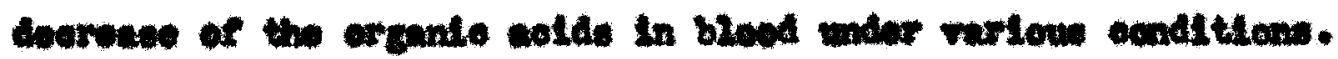


Iranos 


\section{Intions:}

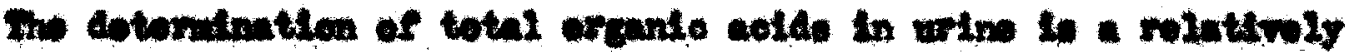

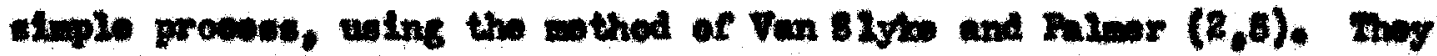

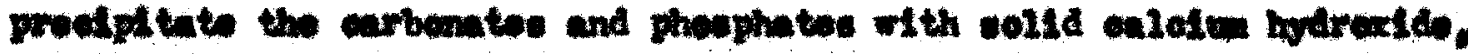

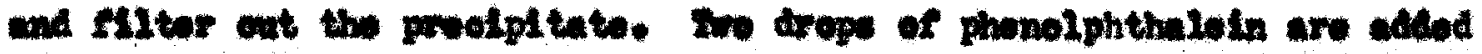

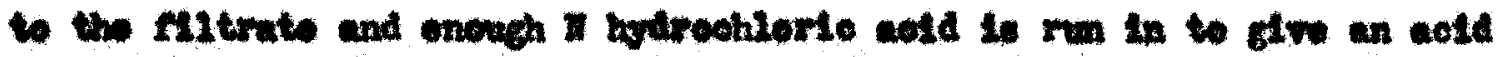

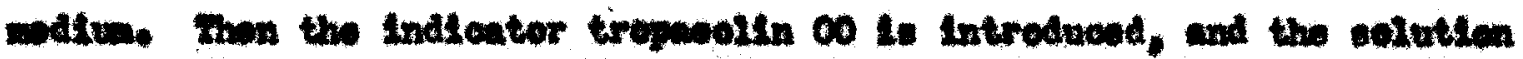

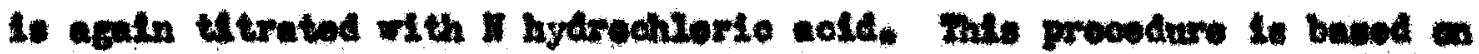

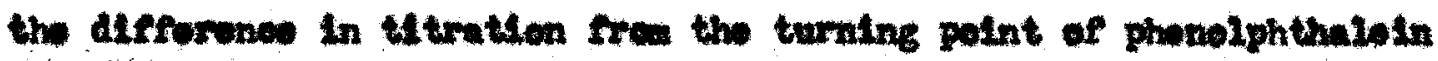
to the turning point of the trepeedin 00 , or frew a gll of 8.0 to ath of 2.3.

wo origind wothed for the orgente oold culoulation in

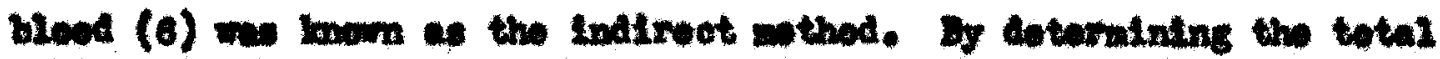
base of the bleed or plame and cubtraotlng froe It the oum of the colde

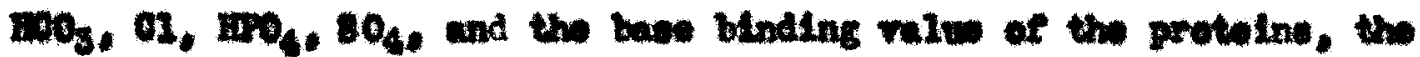

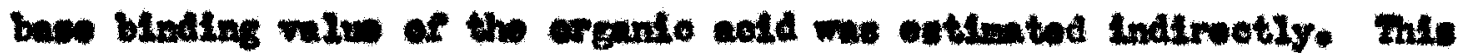

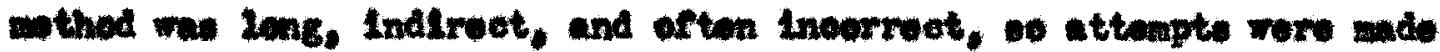

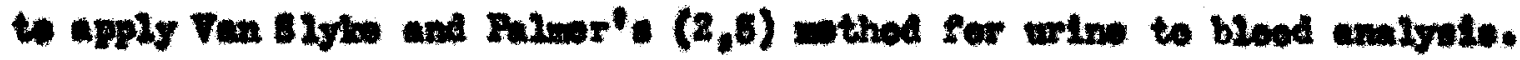

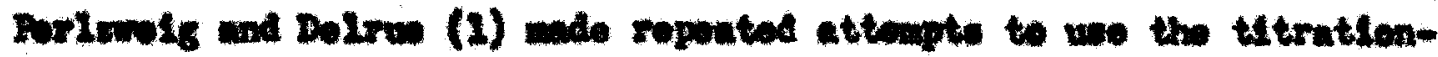

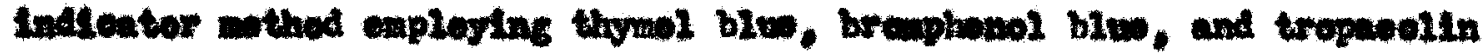

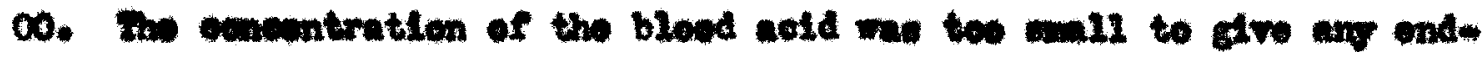

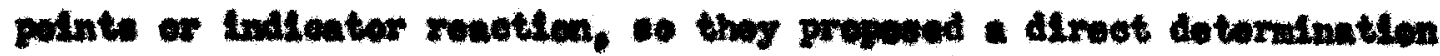

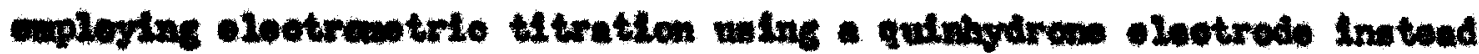
of in Indienter. 
.

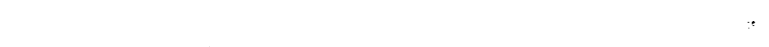

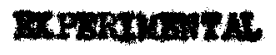


Exrermatu.

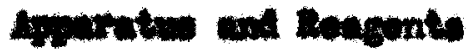

\section{Quinholnome-}

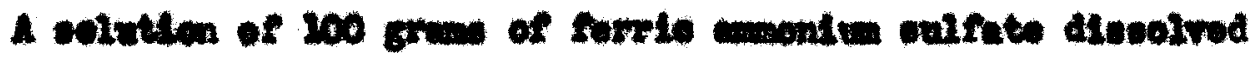

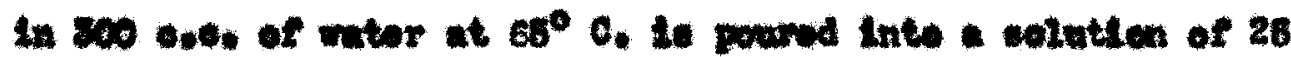

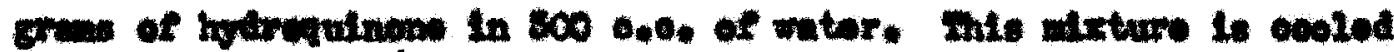

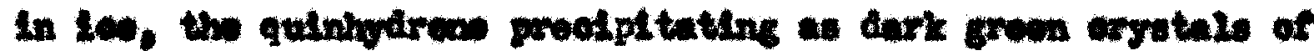

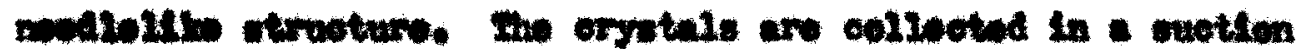

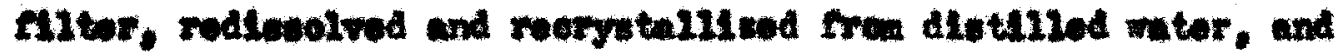

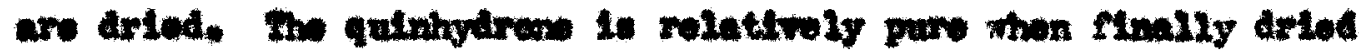
and esileoted.

Oulundrens olectrode.

A gold wre olectrole mich dipe inte tho thtrated selutsen

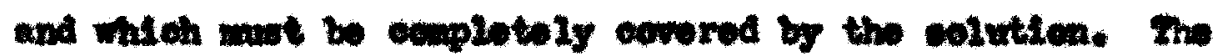

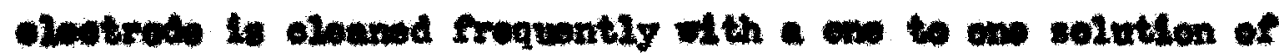
niturte ald and vater.

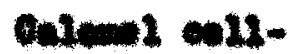

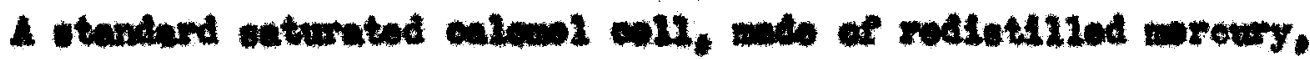

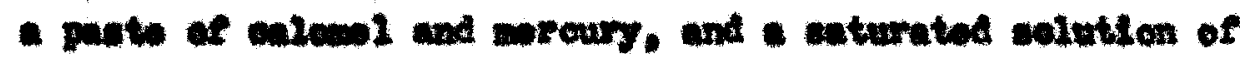

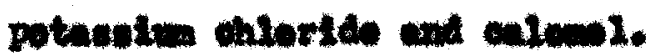

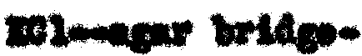

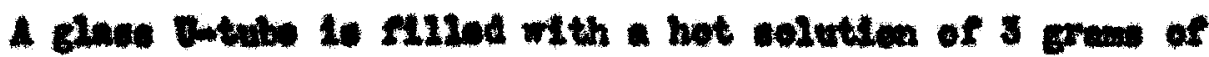

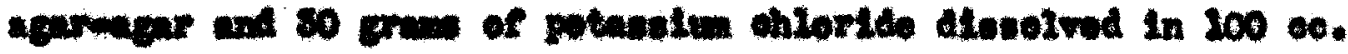




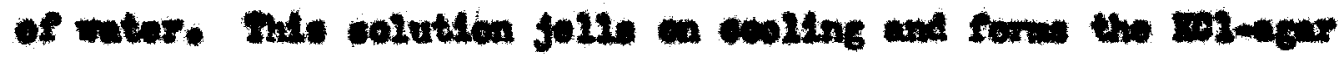

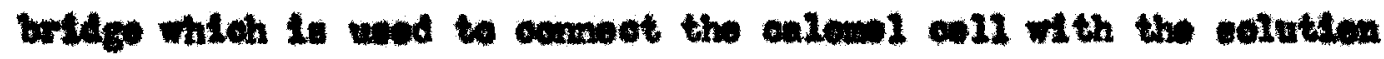

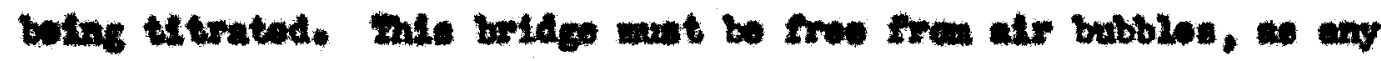

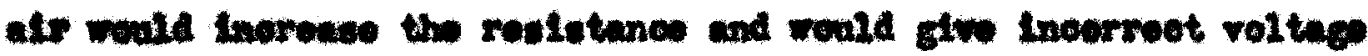

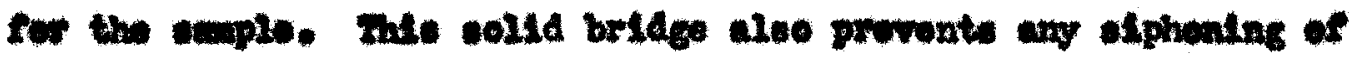

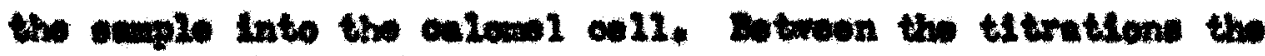

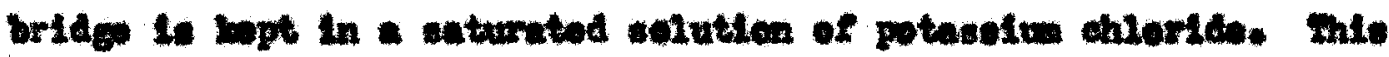

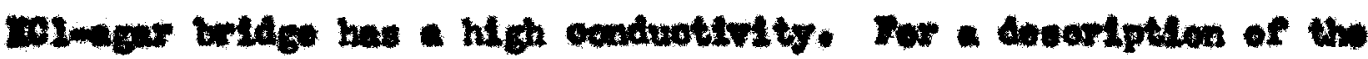
cotmipe nefor to rigure 6.

\section{Eafoure-}

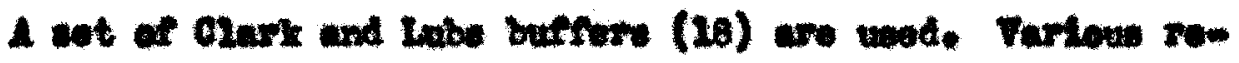

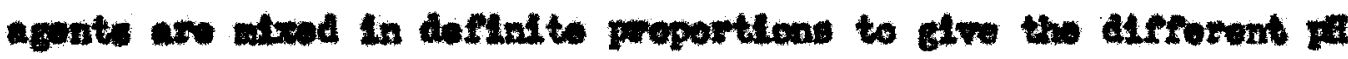

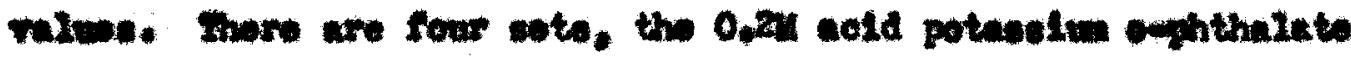

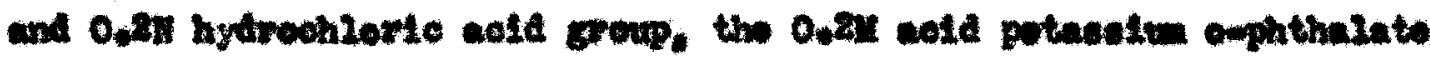

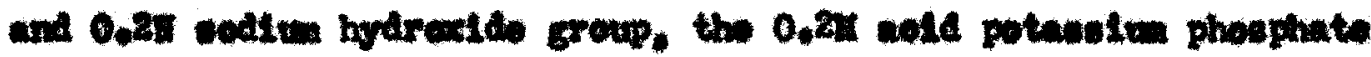

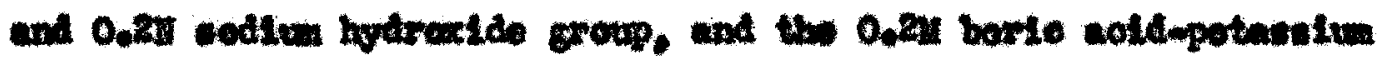

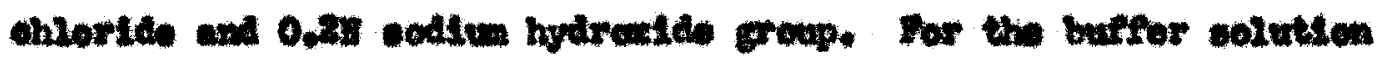
of pt 4.6, which is uned as the burfor ontrol for the blood andplos,

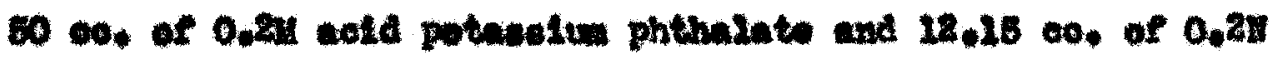

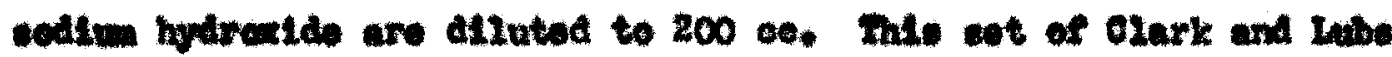

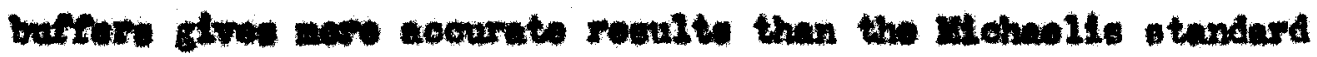

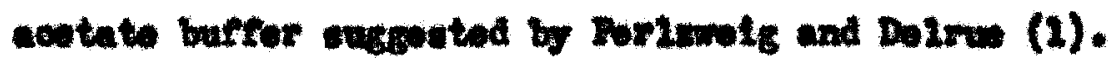

Mo sedtu onierties

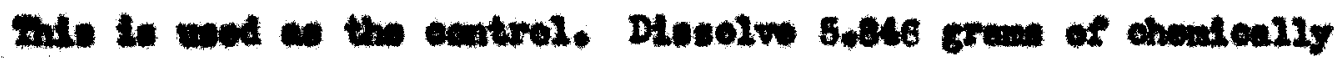

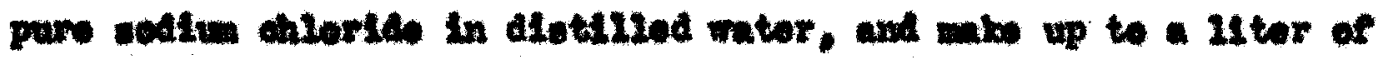
vintion. 


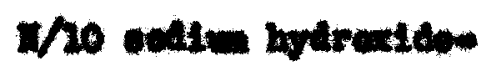

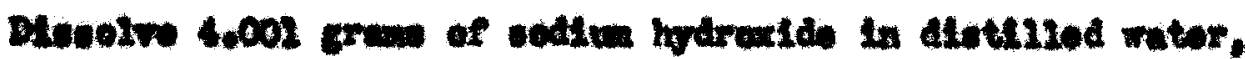

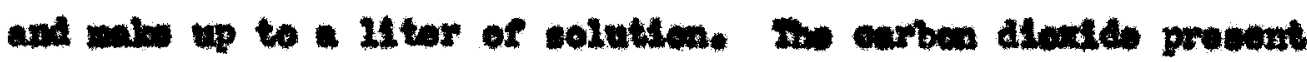

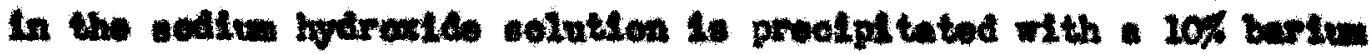

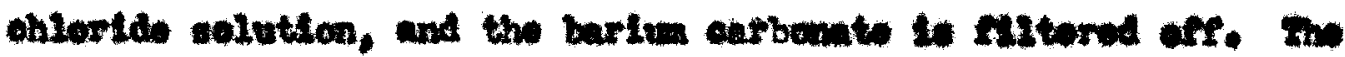

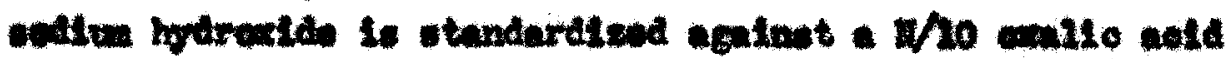

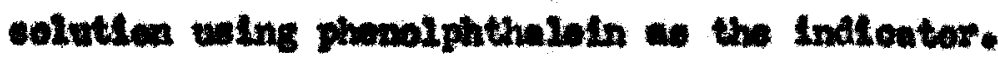

Ompinar oulfute colutlean

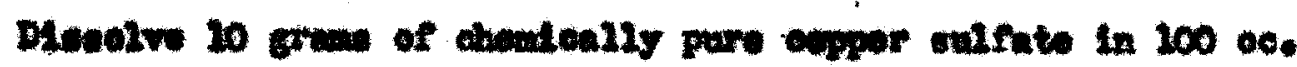

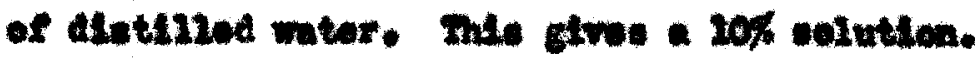

7. hydroahlorte wela-

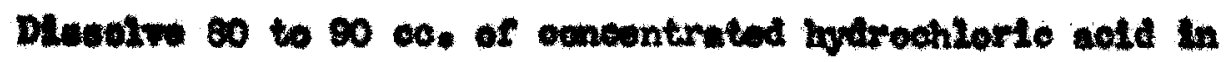

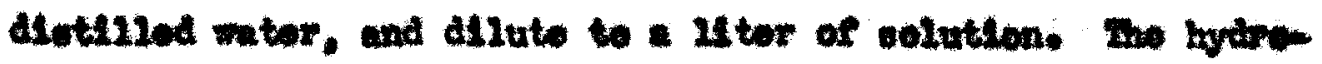

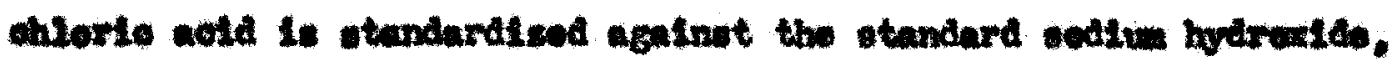
uelng whert orwes os the indionter. 
Wa9150098 
Froouneres

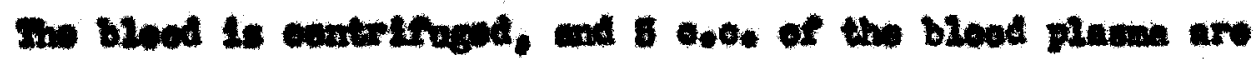

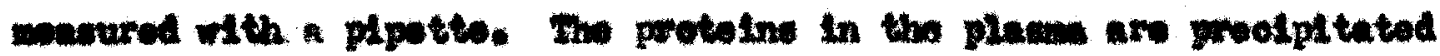

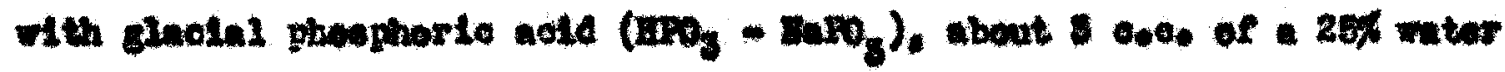

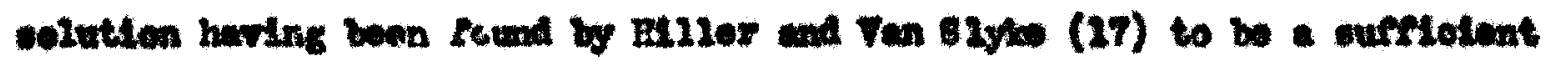

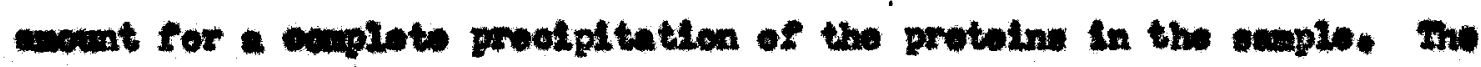

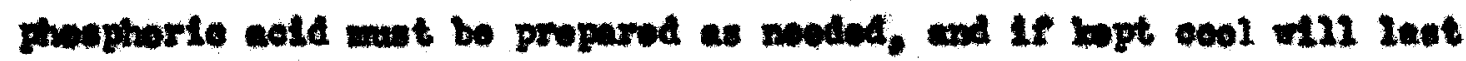

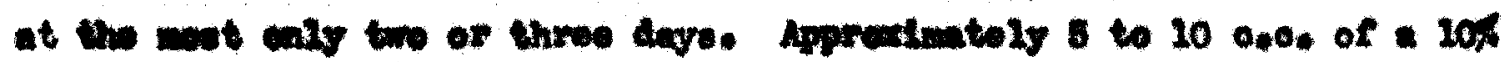

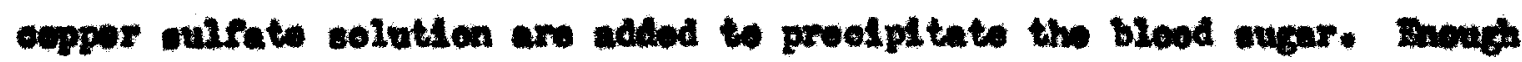

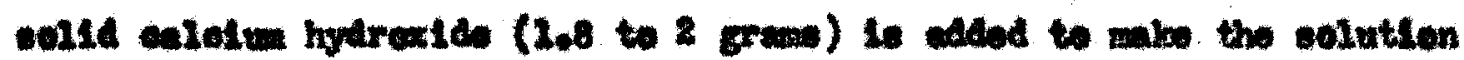

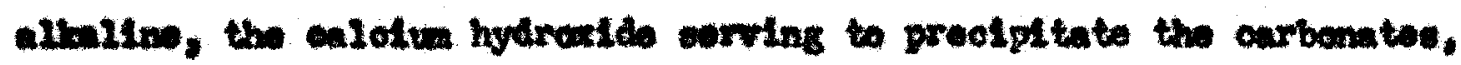

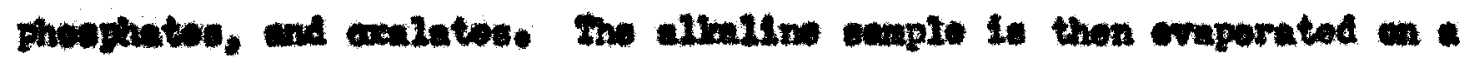

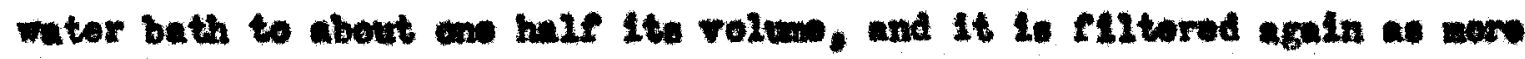

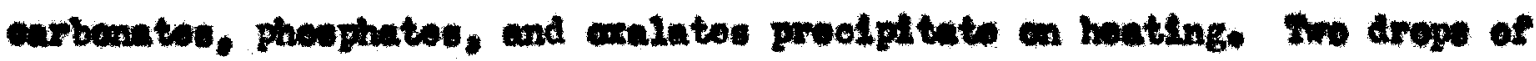

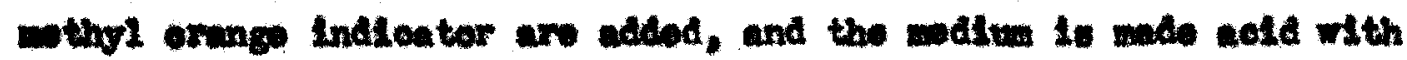

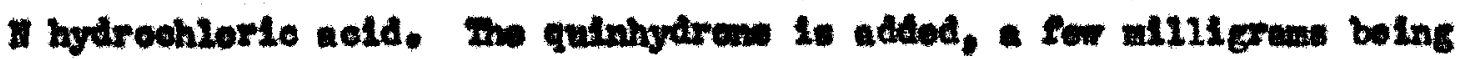

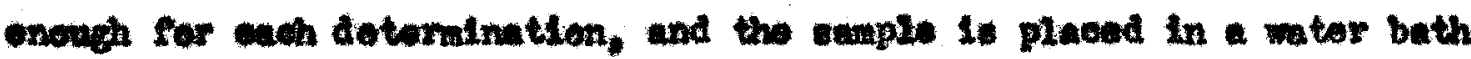
at $26^{\circ}$ o. The quinhydrow lootrods is placed in the edvition, and care mast be tabon that the gold wire of the eleotrode te oempletely covered by

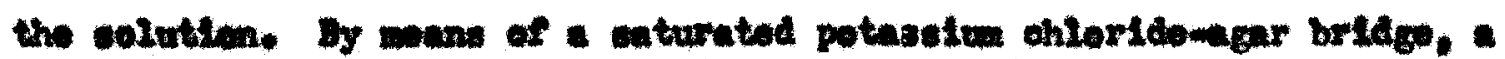

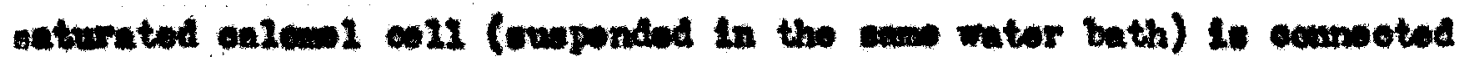

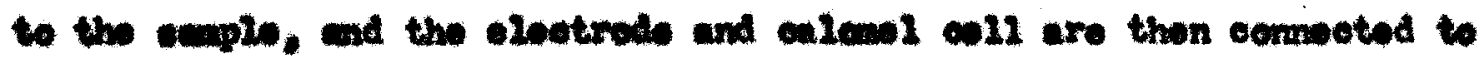

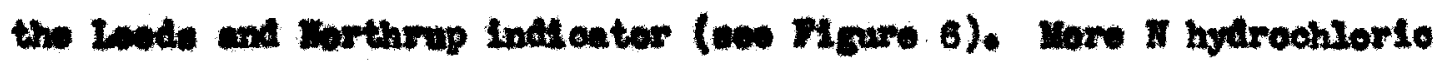

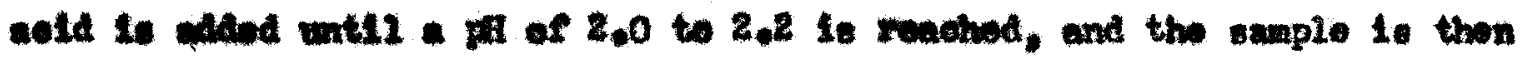

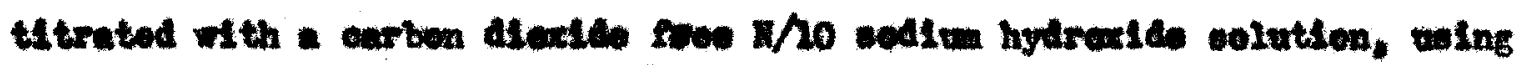




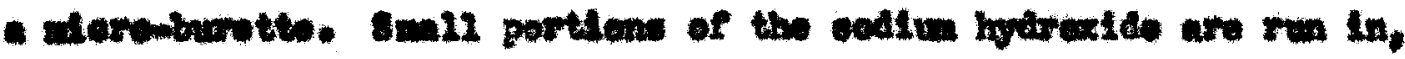

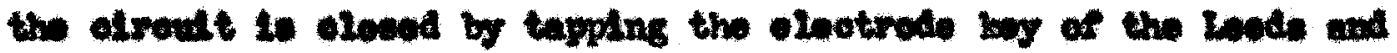

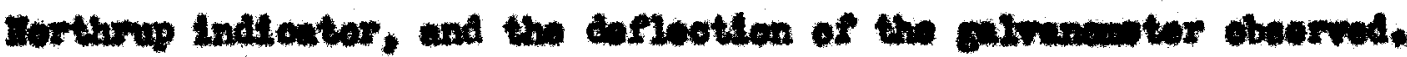

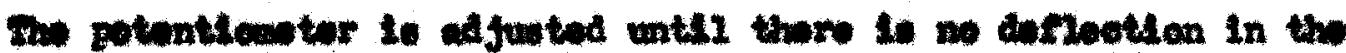

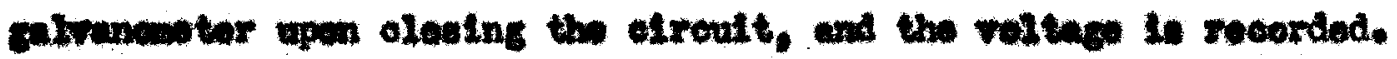

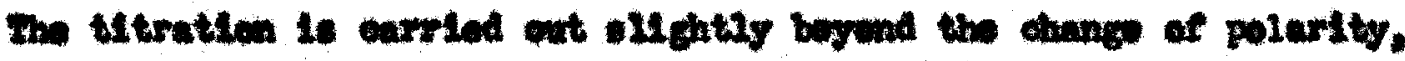
or to a pall of 8.0 to 8.6 .

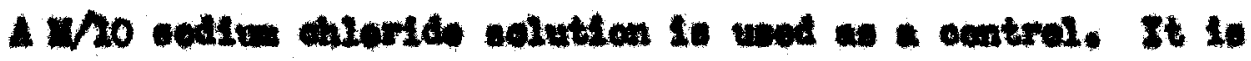

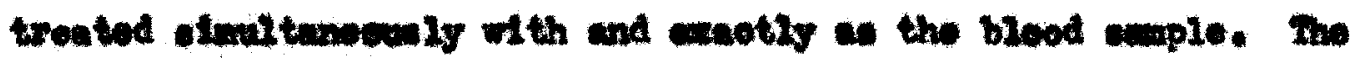

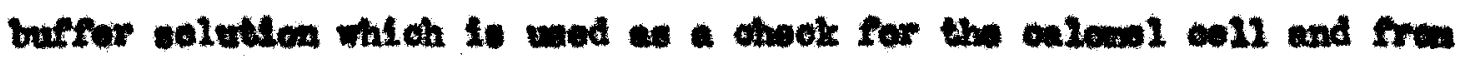

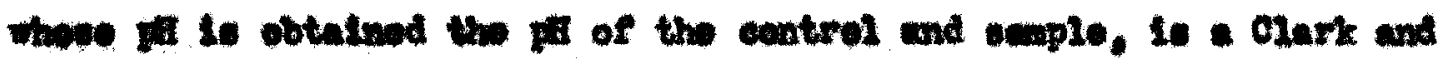

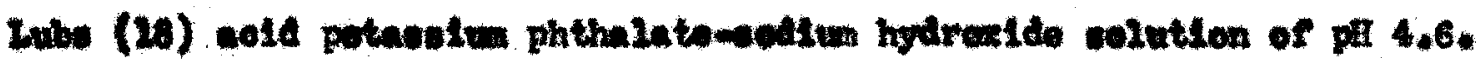

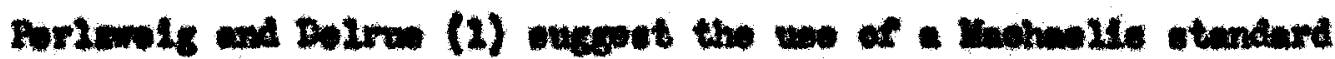

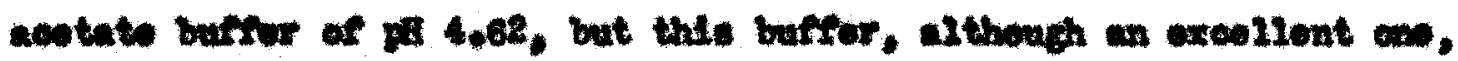

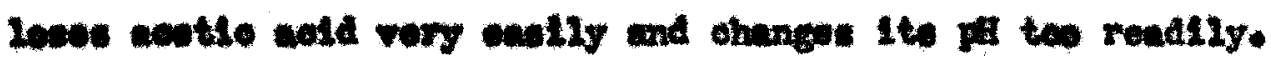

Th II ralwes of the eeatrols and anplos my be obtainod fren the valw for the buffor fres the follening equation-

$$
p^{1}=4.62+\frac{5}{2}-\mathbf{z}
$$

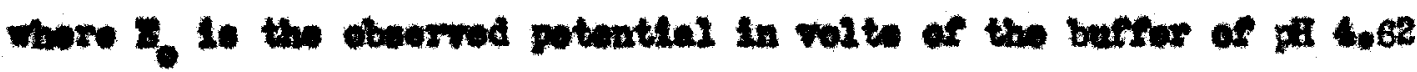

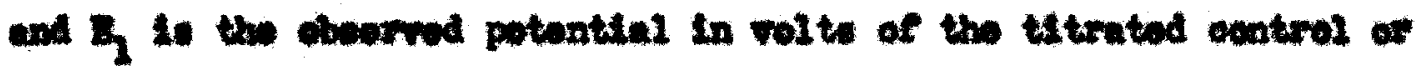

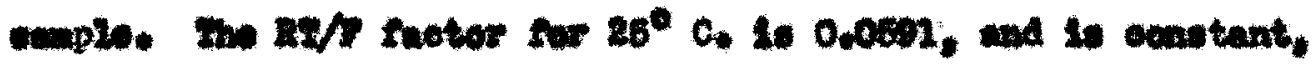

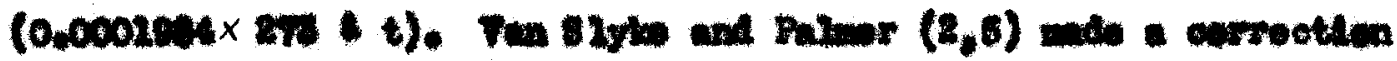

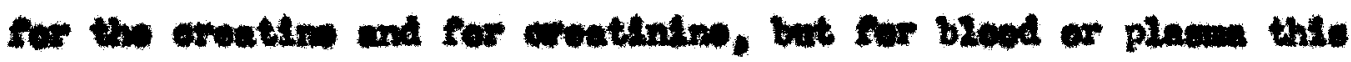
corrootlen is notiglble.

Ourve twe the bied plesme and for the edive ohloride

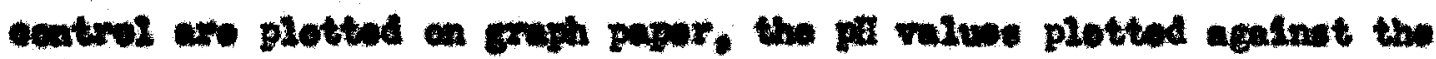




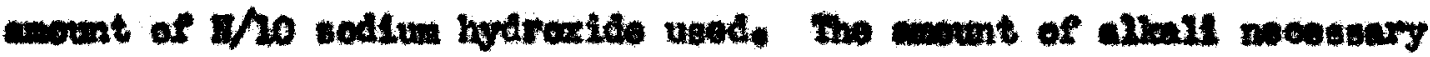

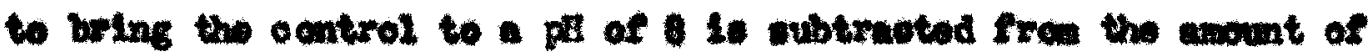
alvall noweseary to bring the blood womple to a pi of 8 , giving the

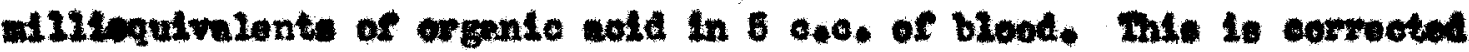

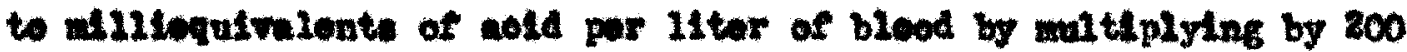
and, oorrooted to militequivilont of nownel alkil by dividing by 10. The final enomer is in alliloquivalentw of normal sold per liter of blood. 

Evie 1.

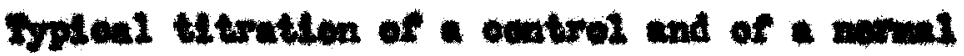

blecd sumple.

control -

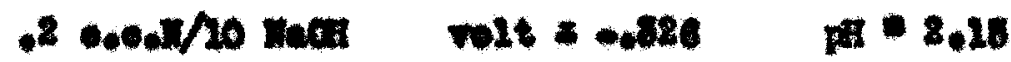

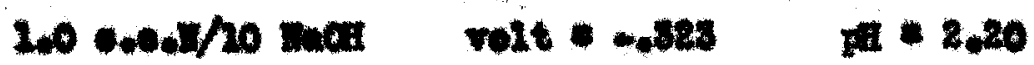

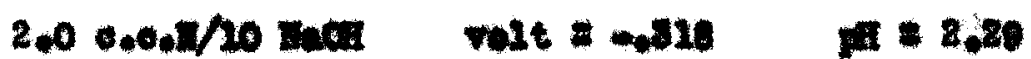

$8,00.0 .4 / 20$ magh rest $=-34$ wa $: 2,30$

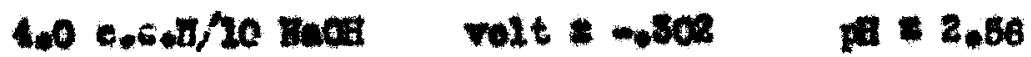

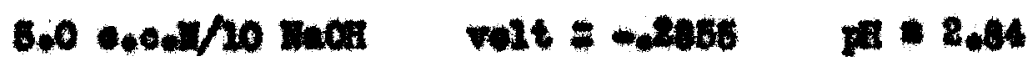

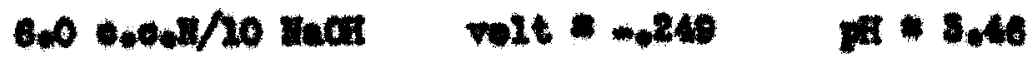

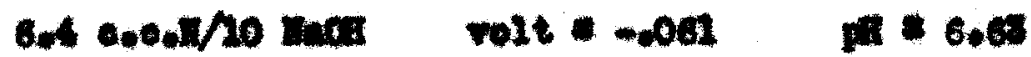

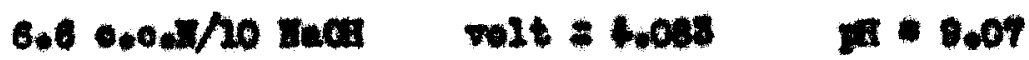

Deed anplo-

\begin{tabular}{|c|c|}
\hline $2 \cos / 10 \mathrm{miax}$ & $\operatorname{volt}=-026$ \\
\hline $1.0000-x / 20$ & wext $=-0386$ \\
\hline $100.0 \times 1$ & rett $=-328$ \\
\hline $3,0 \cdot 0.07 / 20 \mathrm{mmat}$ & velt $=-a 12$ \\
\hline he. a.4.n/no & relt $=$ \\
\hline 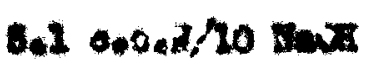 & nit $=-287$ \\
\hline 0 e.call/10: & velt $:-262$ \\
\hline $3.500001 / 20$ matat & volt --222 \\
\hline $06 \cdot 0,4 / 201$ & vets $=-.12$ \\
\hline$\Delta, 0$. & \\
\hline
\end{tabular}


ante 2.

spleal bitration of acatrol and of a blood ouple Iren noirial progrineg.

6antrol-

\begin{tabular}{|c|c|c|}
\hline 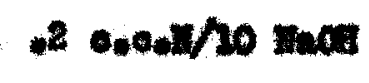 & $\operatorname{velt}--428$ & 12.2 .17 \\
\hline $2,00.0+1 / 10$ mant & w16 -310 & wis $=2.27$ \\
\hline 2,0 cos. & wat -400 & $x=2,4$ \\
\hline $3.0 \cdot 0.0 .1 / 20$ maga & valt $=-234$ & $D=2.70$ \\
\hline $8,80.0 .4 / 10$ Dnor & volt = - maes & D $=2,05$ \\
\hline $4.0 \cdot .4-1 / 10 \operatorname{lima}$ & $v e 2 t=-251$ & $p=8.4$ \\
\hline 4.6 c.0.M/ho Dat & volt $=-.12$ & $A=5.00$ \\
\hline $5.00 .00 \pi / 10 \mathrm{~min}$ & relt $=-1020$ & $\mu=0.00$ \\
\hline
\end{tabular}

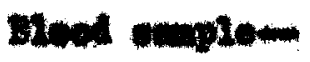

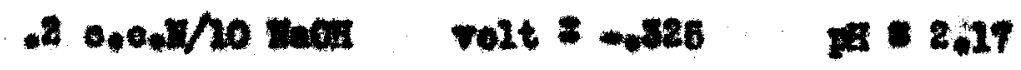

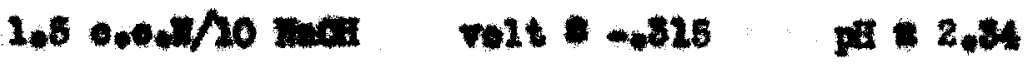

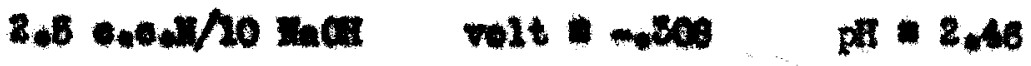

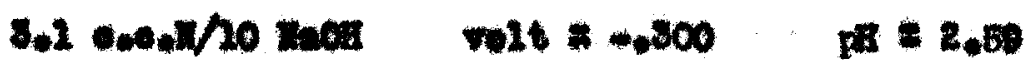

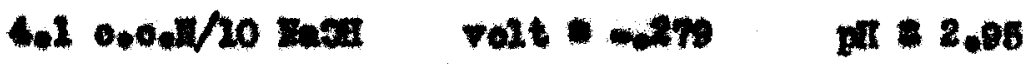

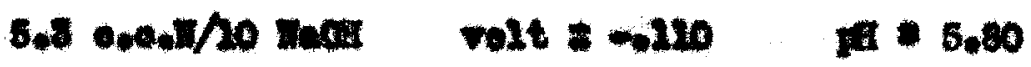

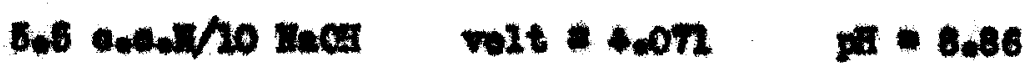




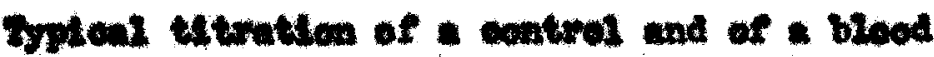

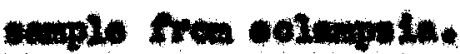

Central-

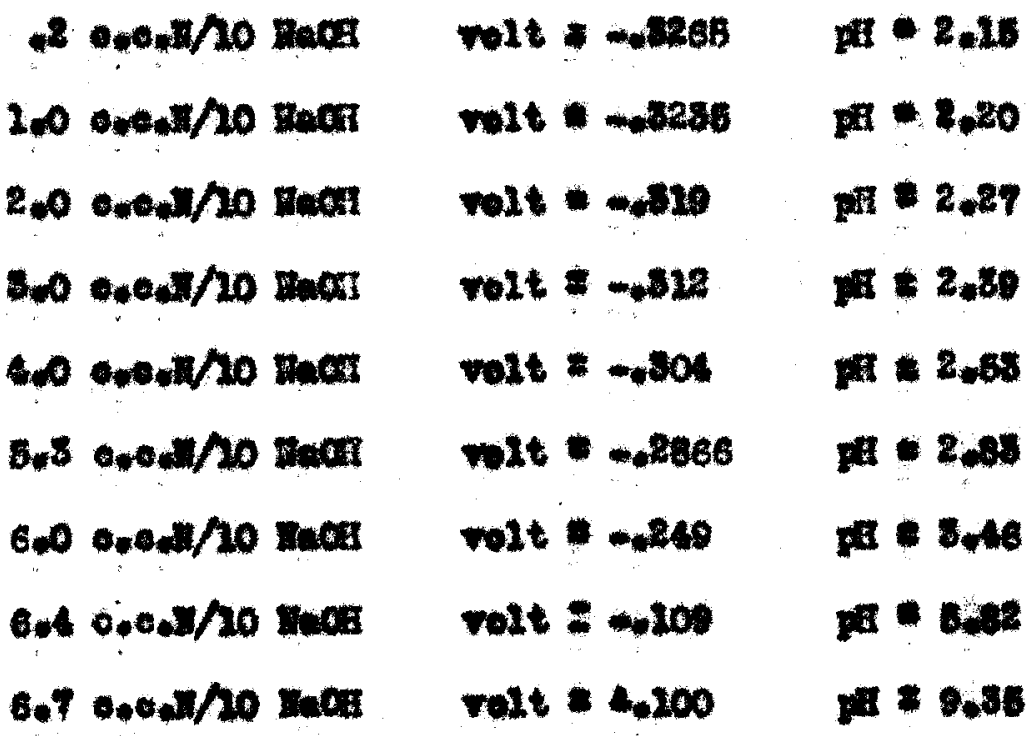

Blow anplom

$2000-1 / 10$ tad rolt $=-4826$.15

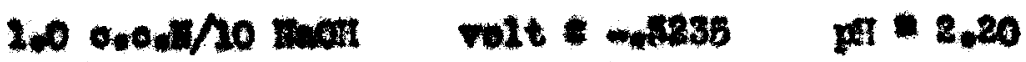

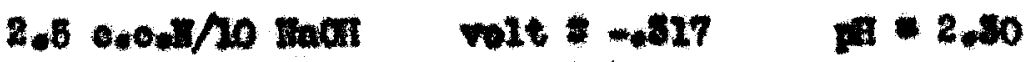

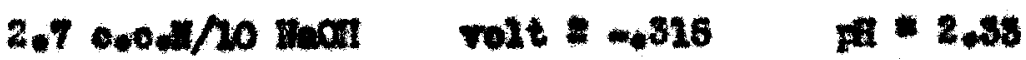

8.5 ever.

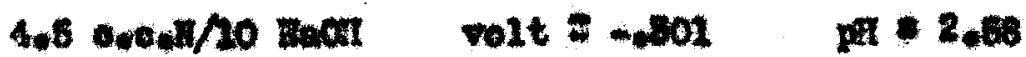

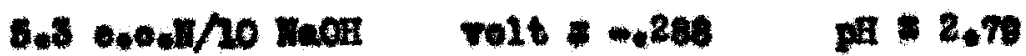

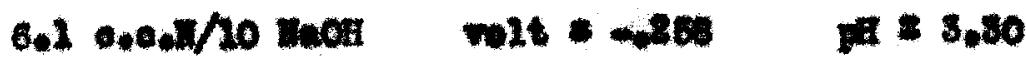

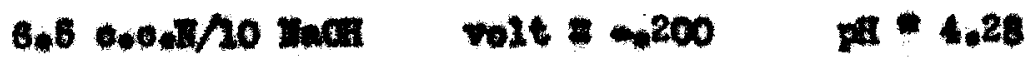

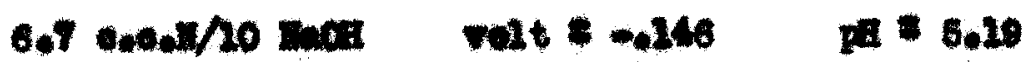

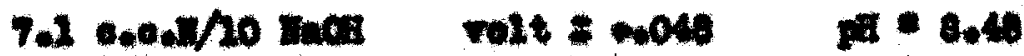




\section{Dable to}

sypent stration of a ontral and of a blood ample tren tubsroulents. Centrol-

\begin{tabular}{|c|c|c|}
\hline $2.0 .0 .1 / 20$ boct & velt $=-.426$ & $\mathrm{pta}=2.18$ \\
\hline $2,00.0 .2 x / 20$ mact & velt $=-.828$ & $x=2,22$ \\
\hline $2.00 .0 .5 I / 20$ WhOH & velt $=-43108$ & $y=2,26$ \\
\hline 3.0 owowho Mach & re16 $\cdot-.314$ & $p=2,36$ \\
\hline $4.00 .04 k / 20$ mact & velt $=-.300$ & pat $=2,46$ \\
\hline $5.0 \cdot 0.0,1 / 20 \mathrm{mon}$ & velt -1500 & $x=2.69$ \\
\hline $6.00 .0 .4 / 10$ lnogs & velt $=-288$ & $\mathrm{p}=2,80$ \\
\hline $7.00 .0, \pi / 10$ & volt $=-209$ & $m=3.12$ \\
\hline 0.0 c.0.4/ 10 nact & volt $=-\alpha 17$ & $\mathrm{pH}=4.77$ \\
\hline $0.30 .0,4=1 / 20$ mad & welt $=-.027$ & pet $=7.37$ \\
\hline $0.850,0,11 / 10$ mact & velt $* 0.020$ & ait $=8.00$ \\
\hline
\end{tabular}
Dead nemple-

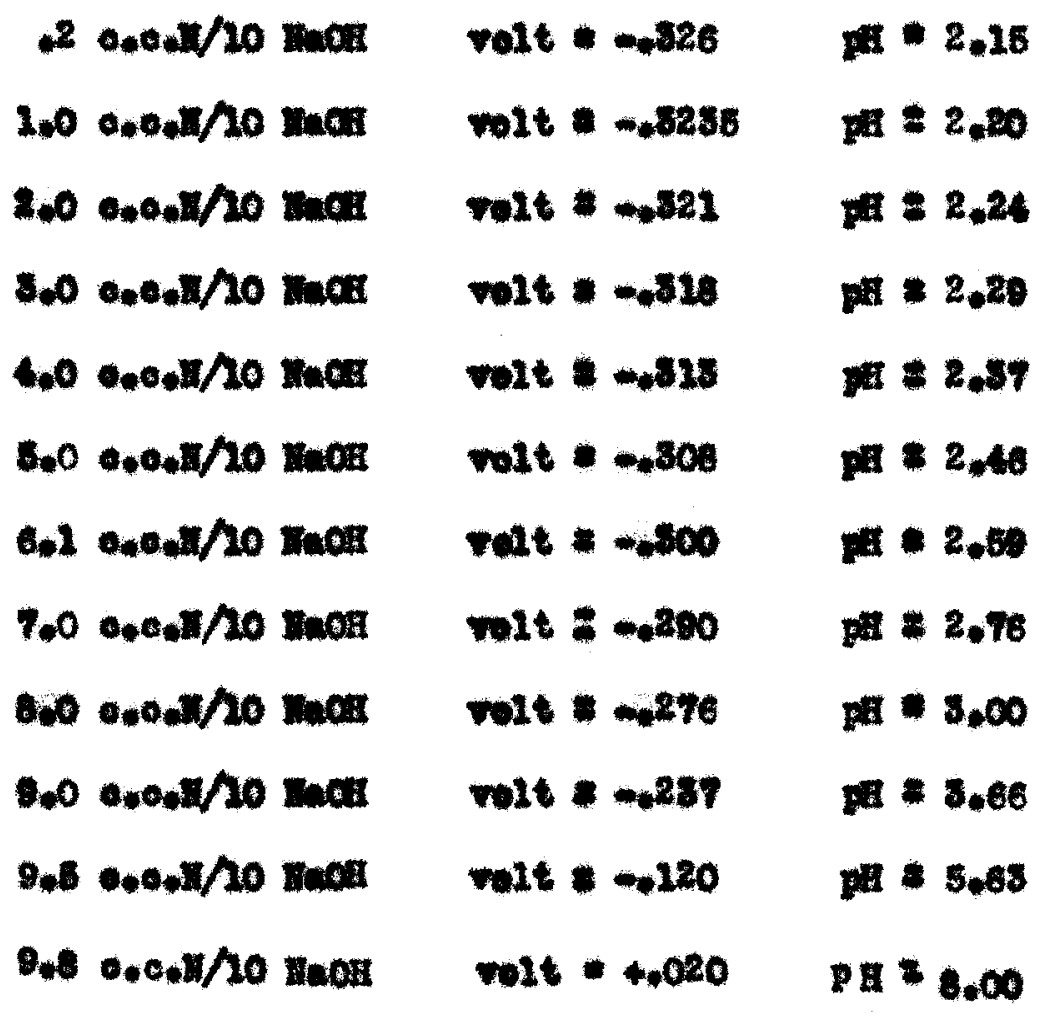


smbie 6.

Typlenl titration of a oentrol and of a bloed anple fro diabotos militua.

\section{Oentarel -}

$20.0+1 / 10$ max

$1000.0 \pi / 10 \mathrm{mach}$

$2,00.00,1 / 20$ mata

$3.00 .0 .01 / 10$ maca

$400.001 / 20$ mata

$8.00 .0 .07 / 10$ sinar

$6.0 \cdot 0.0 .01 / 10 \operatorname{man}$

$7.00,0,0 / 10$ Buca

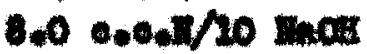

- 2 ive.

0.3 e.con/10 Maga

Bused semple-

$.20 .0 .17 / 20$ bara

$2.0000 .47 / 20$ nach

$2.0000 .0 \mathrm{~m} / 10$ mator

$5.00 .0 \times 1 / 20$ mos

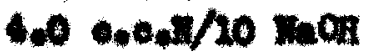

6.0 cosit/10 Inor

$6.00 .0 .11 / 20 \mathrm{mat}$

7.0 cotakn wian

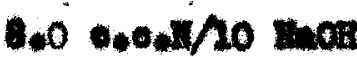

0.2 0.0.minto mat

9.6 0.0.4ho saca

Do osoull/20 taon wolt $=-0.9265 \quad \mathrm{gA} * 2,16$

velt.,- 822 . 2.28

velt $=-0.618$ fill $=2,29$

vat $=-.848$ in 2.37

velt $=-307 \quad$ pR $=2,4$

wit $=-200$ pt $2_{, 64}$

vit $=-288 \quad u=2,00$

volt $-.266=3,4$

-1t $=-0166 \quad p-8.02$

velt $=-028 \quad$. $12 \cdot 7.10$

w1t $=+040$ ft $=8.34$

velt $=-326 \quad$ HI $\geq 2,17$

volt $=-324 \quad$ yt $=2.20$

volt $=-.221 \quad p=2.24$

velt $=-.328 \quad$ pit $=2.29$

volt $=. .318$ जa 2,37

volt $=-.307$ pel $=2.4$

ralt $-5 \operatorname{son} \quad$ pr $=2.60$

velt $=-290 \quad r=2,70$

volt $=-274 \quad$ pt $=3,00$

velt $=-224$ pit $=5.98$

velt $=-0100$ fal 5.07

volt $\$ .0020$ pil 8.00 
22.

able 6.

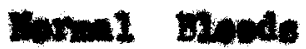

Bumie Dato Miliogutrient:

$12 / 60 / 3$

$22 / 40$

$2 / 18 / 28$

$42 / 25 / 68 \quad 20$

5 2/27/83

- 8/6/25 4

7 3/20/58 8

$3 / 20 / 05$

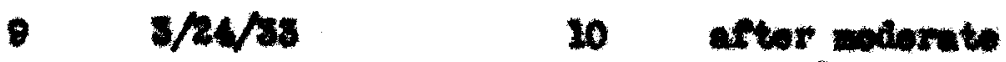

extarolle

$10 \quad 3 / 2 / 4$

11. axter moro

snowe corales 
anble 7 .

Darial Propaney

\begin{tabular}{|c|c|c|}
\hline Mlood ratople & $D+4$ & 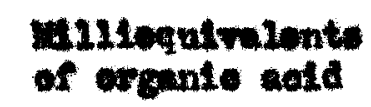 \\
\hline 1. 0 & $\$ / 28 / 08$ & 8 \\
\hline 2. H. & $3 / 26 / 28$ & 10 \\
\hline B. & $4 / 20 / 6 s$ & 10 \\
\hline s. & 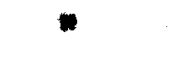 & 6 \\
\hline n. & 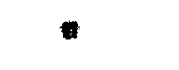 & 4 \\
\hline
\end{tabular}


subto 8.

\section{Deleuginta}

\begin{tabular}{|c|c|c|}
\hline Elowa enmple & Date & $\begin{array}{l}\text { Allieguivinente } \\
\text { of ergente sold }\end{array}$ \\
\hline R. L. & $2 / 17 / 35$ & 6 \\
\hline 0.8 & $2 / 27 / 35$ & 8 \\
\hline$x_{0} a_{0}$ & $/ / 2 / 3$ & 4 \\
\hline 1. 1. & $s / 4 / 88$ & 10 \\
\hline
\end{tabular}


Takle 9.

Puimenary tubsroblots

\begin{tabular}{|c|c|c|}
\hline Bened ounpe & Dute & 4ixlequivilonts \\
\hline d. 6. & $4 / 22 / 03$ & st \\
\hline D. 2. & - & 20 \\
\hline An $w_{*}$ & $\bullet$ & 38 \\
\hline 4. n. & $4 / 22 / 43$ & 24 \\
\hline 4. 0. & n & 29 \\
\hline B. 0 . & 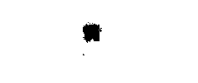 & 28 \\
\hline 1. I. & $"$ & 21 \\
\hline D. to. & " & - \\
\hline a. 3. & $\bullet$ & 84 \\
\hline
\end{tabular}


26.

nabie 10.

\section{Diabotes Donstus}

\begin{tabular}{|c|c|c|c|c|c|}
\hline 3 ample & Date & Condtuten & $\begin{array}{l}\text { Minfequivalente } \\
\text { of ergonte aste }\end{array}$ & $\begin{array}{l}\text { nowa } \\
\text { suger }\end{array}$ & \\
\hline 3. 8 . & $3 / 27 / 08$ & mod, sover. & 80 & 48 & no \\
\hline I. D. & $8 / 10 / 5 s$ & $\begin{array}{l}\text { mod. sovore } \\
\text { cotidenis }\end{array}$ & 20 & 100 & inculla \\
\hline C. $B$. & $3 / 20 / 03$ & mod. acwark & 86 & 220 & * \\
\hline 2.0. & $8 / 20 / 58$ & wla & 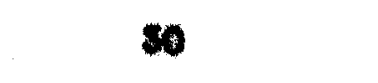 & 260 & " \\
\hline 4. & $8 / 20 / 28$ & $\begin{array}{l}\text { mod. sevore } \\
\text { aoldeate }\end{array}$ & 26 & 260 & 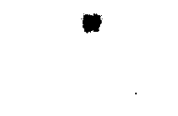 \\
\hline t. B. & $3 / 27 / 5 s$ & mild & 0 & 162 & 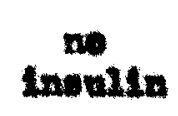 \\
\hline N. B. & $4 / 20 / 48$ & med. worers & 4 & 100 & Inenile \\
\hline R. $P_{0}$ & $4 / 24 / 38$ & mod. sowere & 26 & 200 & " \\
\hline
\end{tabular}


tbiv 21

Dabte: Noluta

\begin{tabular}{|c|c|c|c|c|c|}
\hline semplo & Bute & Gondtution & $\begin{array}{l}\text { MR11matrolents } \\
\text { of orgento aots }\end{array}$ & $\begin{array}{l}\text { Hzeed } \\
\text { onger }\end{array}$ & \\
\hline \multirow[t]{2}{*}{ E. $P_{0}$} & $8 / 20 / 58$ & adderis & 4 & 222 & Invulen \\
\hline & $8 / 27 / 53$ & & $\mathbf{x}$ & 182 & \\
\hline \multirow[t]{4}{*}{ B. B. } & $3 / 47 / 68$ & mod, entere & $\mathbf{E}$ & 268 & Inoults \\
\hline & $4 / 010$ & & 10 & 222 & \\
\hline & $4 / 20 / 08$ & & 4 & 260 & \\
\hline & 1/27/sos & & 2 & 220 & \\
\hline \multirow[t]{4}{*}{0.6.} & $3 / 27 / 58$ & $\mathbf{1 1 2}$ & 40 & 222 & Inmalla \\
\hline & $1 / 6 / 63$ & & 32 & 142 & \\
\hline & $4 / 10 / 03$ & & 26 & w: & \\
\hline & $1 / 7 / 28$ & & 20 & 240 & \\
\hline \multirow[t]{5}{*}{ 4. 2.} & $8 / 27 / 88$ & wird & 30 & 200 & $\min _{\text {ingen }}$ \\
\hline & $4 / 5 / 68$ & & 33 & 206 & \\
\hline & 4/20/6s & & 22 & 200 & \\
\hline & $4 / 17 / 0 s$ & & $\mathbf{s}$ & 220 & \\
\hline & $1 / 4 / 38$ & & 44 & 240 & \\
\hline \multirow[t]{3}{*}{ a. 0.} & $3 / 02 / 08$ & ald & 46 & 266 & Inowit: \\
\hline & $4 / 2 / 85$ & & 34 & 106 & \\
\hline & $4 / 2 / 85$ & & - & 138 & \\
\hline \multirow[t]{2}{*}{$x_{0 .} \mathbf{z .}$} & $4 / 2 s$ & med. wener & - & 358 & inovitin \\
\hline & $4 / 17 / 68$ & & 16 & 300 & \\
\hline \multirow[t]{2}{*}{ E. 1.} & 4ho/as & axd & 6 & 228 & Invertin \\
\hline & $4 / 7 / 6$ & & 5 & 220 & \\
\hline
\end{tabular}


Heras 


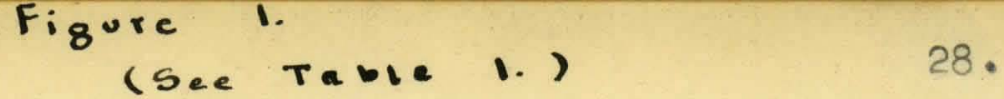

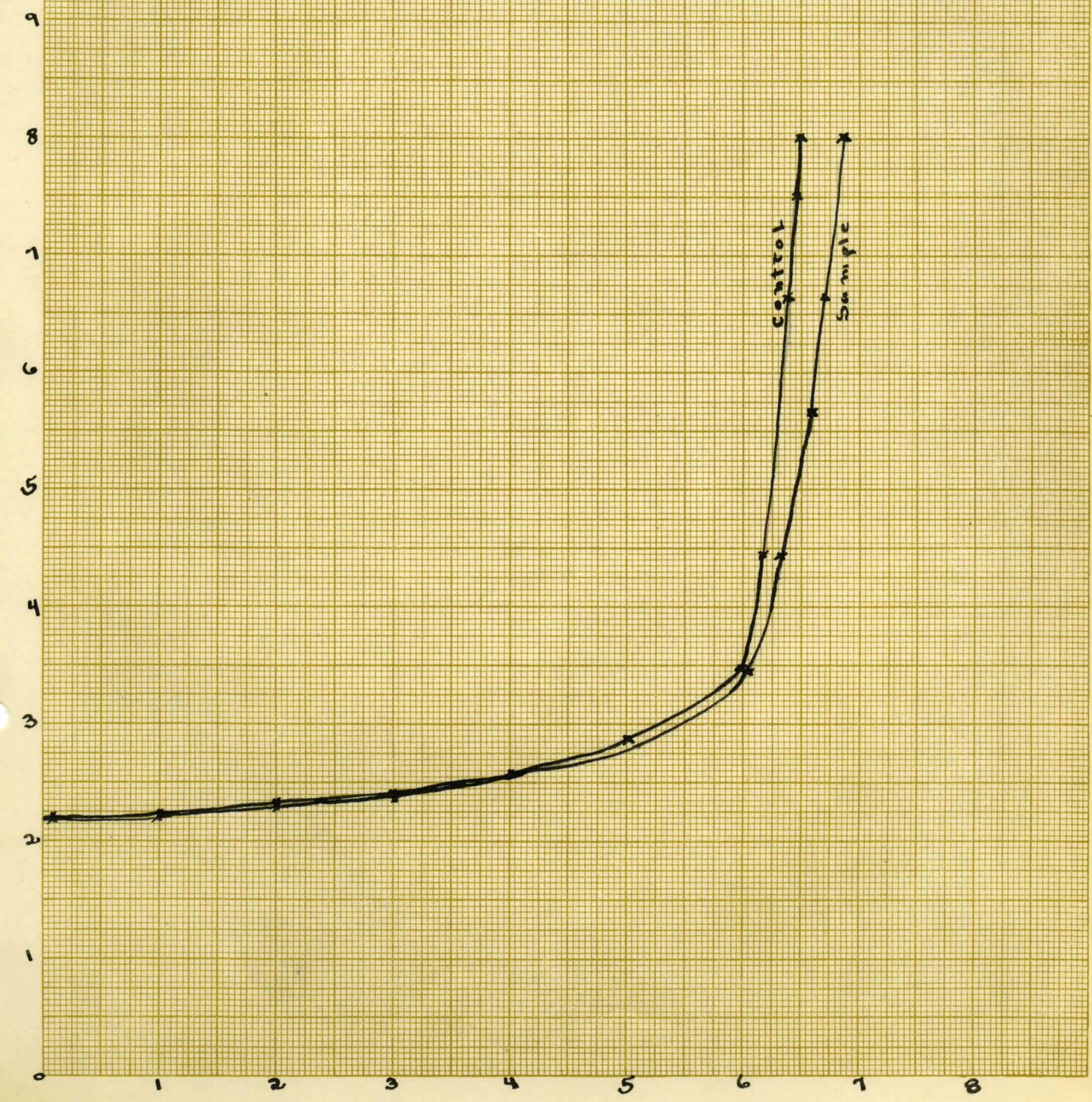

c.c. $m / 10$ haot 
Figure 2

(See Table 2) 


$$
\begin{aligned}
& \text { Figure }{ }^{3} \\
& \text { (Sec Table 3) }
\end{aligned}
$$

$$
\text { c.c. m/10 } \mathrm{Ne}-4
$$




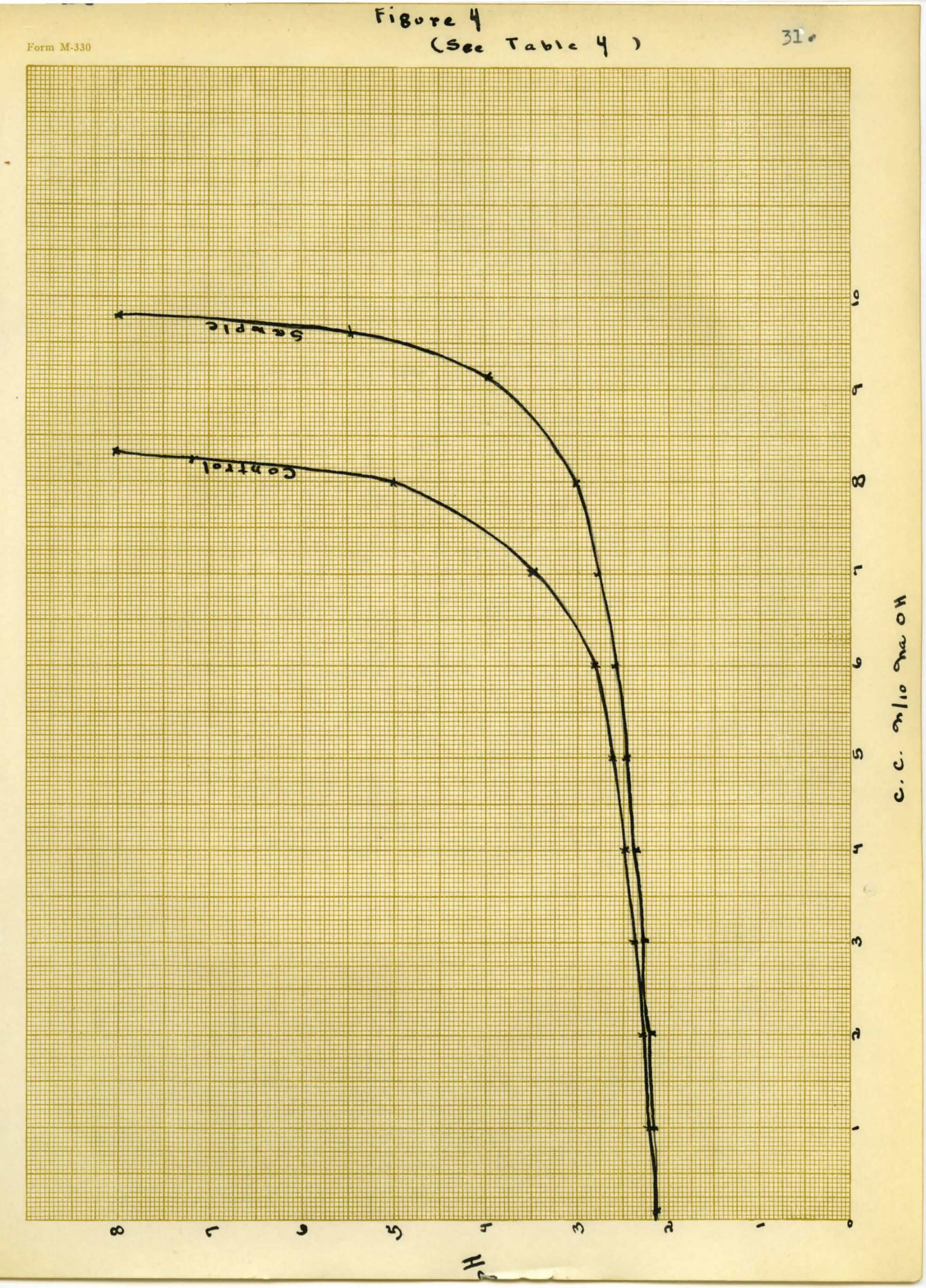




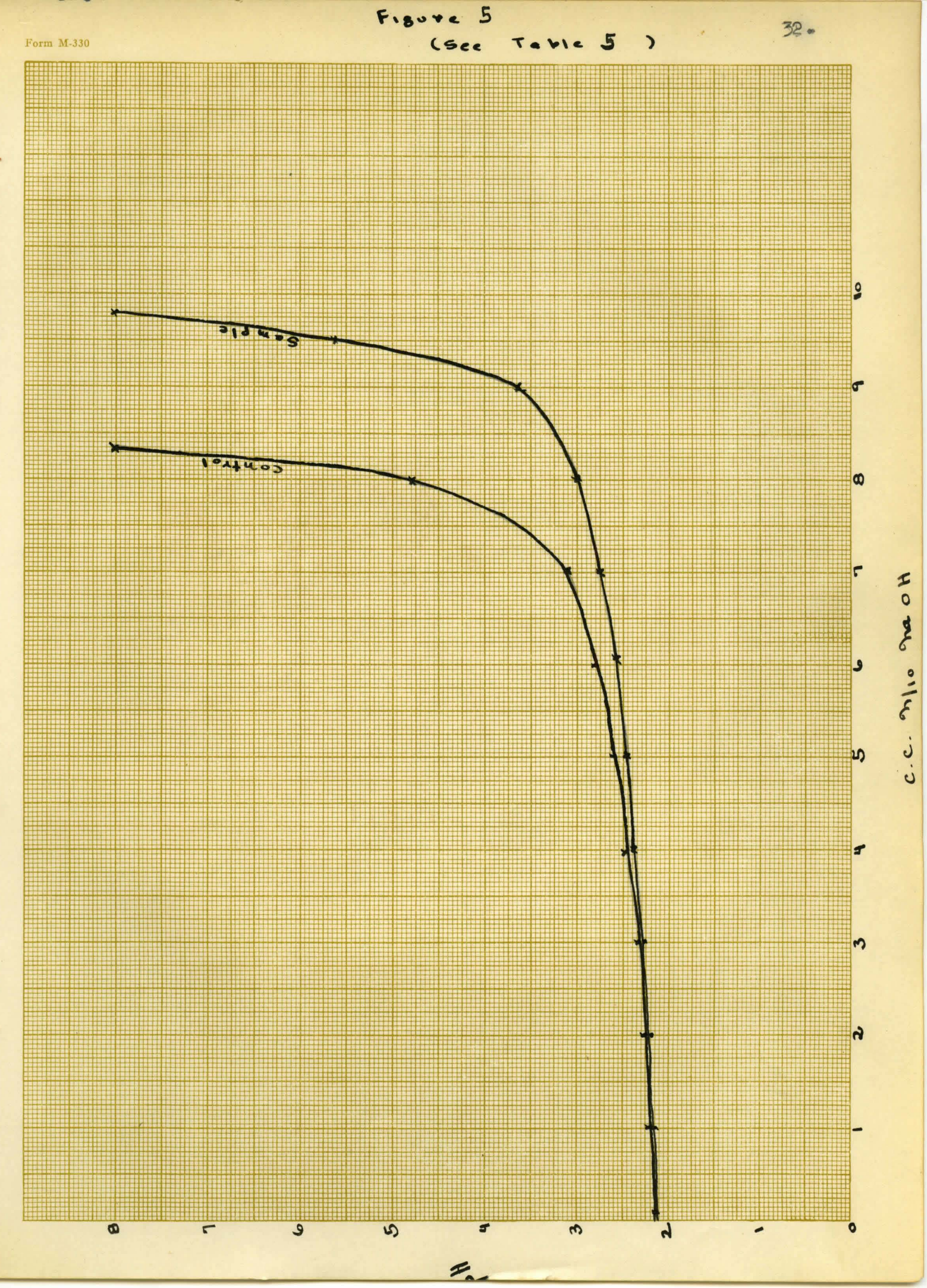




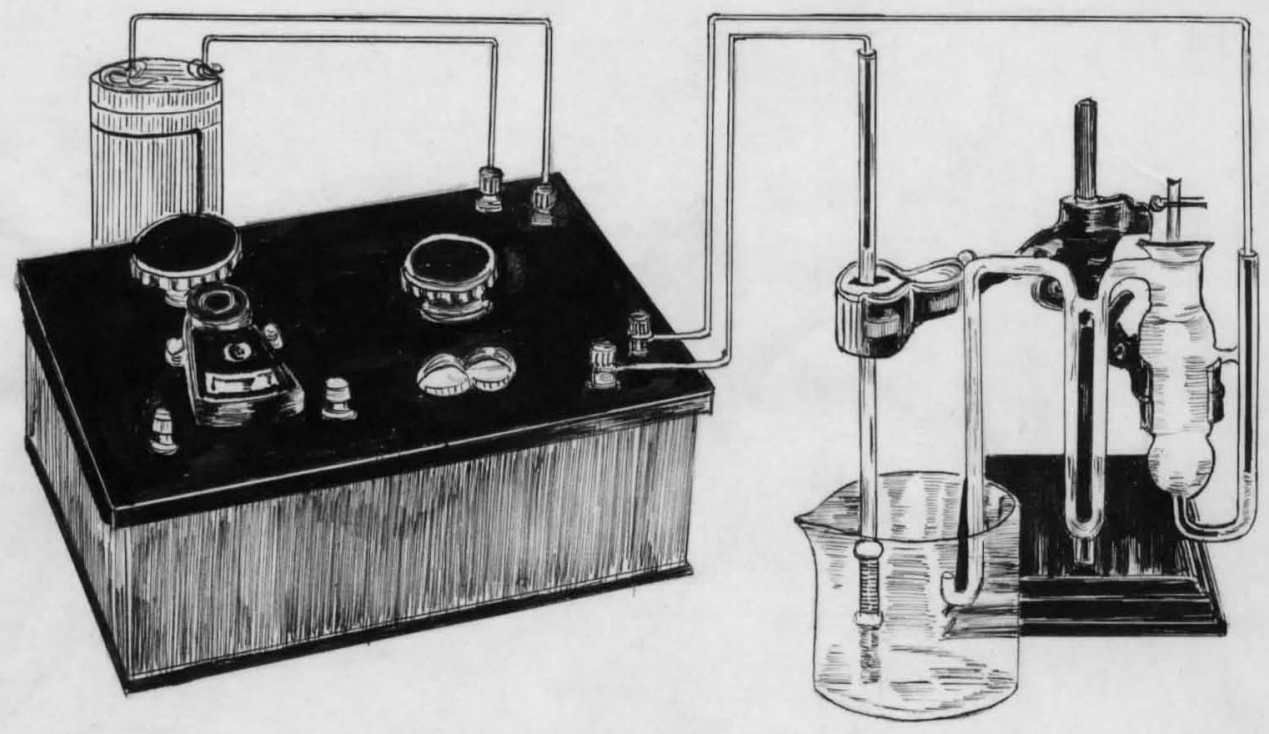

Figure 6 
DDCos ram 
Des cuss zor

Wth the excoption of the work reportied by Borlemets and DeIrw (1). all the doteralnations of the creanie aold oentont of

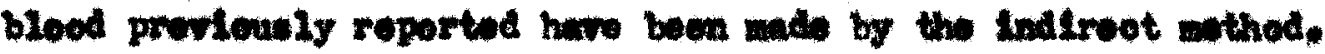
The data obtalnad by noe of the quinhydrow olootreds wothed in the invoutlgatlen is compared in the following pagen with thowe valwe

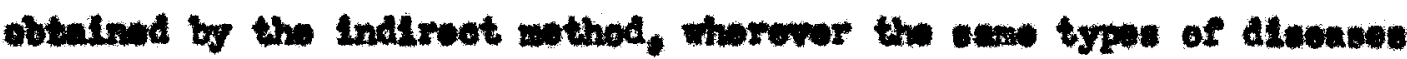

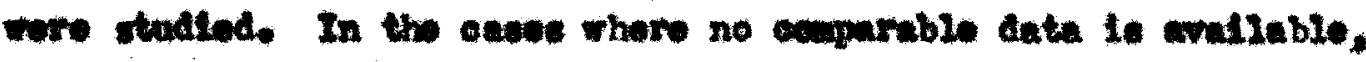
the rulue are interperted on the bacle of the known hote regarding

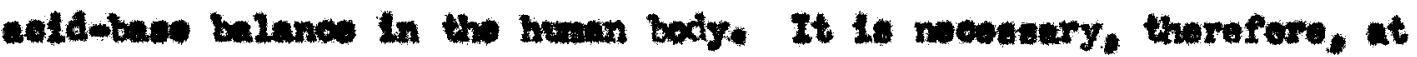

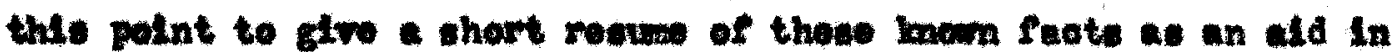
the Interprotatien of the velwe given in trbles 6 to 11.

The bute elewents of the blood and tisevos omulat sleost

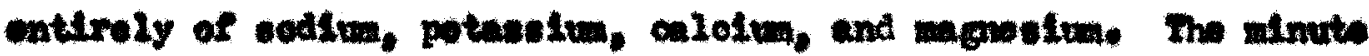
moute of the other besio material are nogilgible. At reactlon so

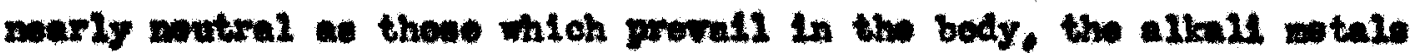

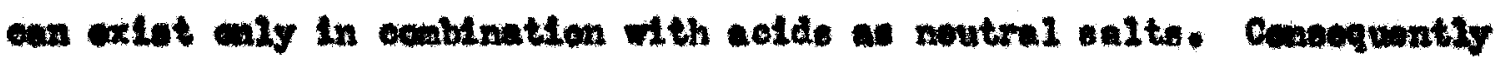

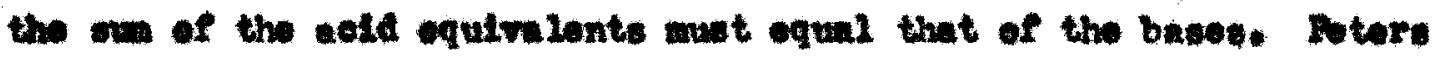
and Fon slyhe (7) have expresed thls relation graphloully for avorage plewn in the following manner:-

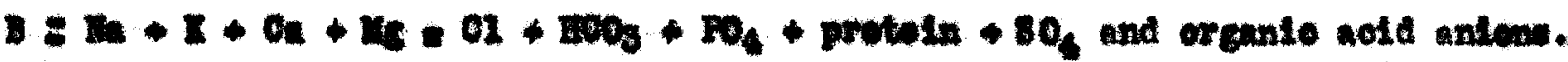
$188 \times 42+6+5+3 \div 103+28+2+16+$ 6

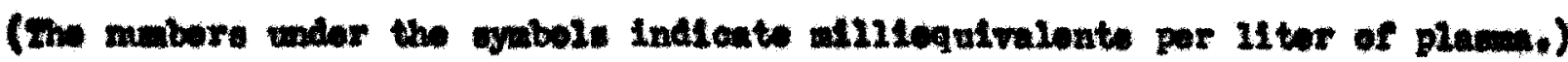

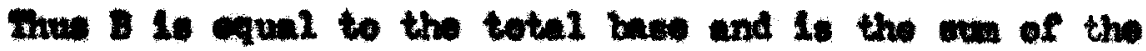

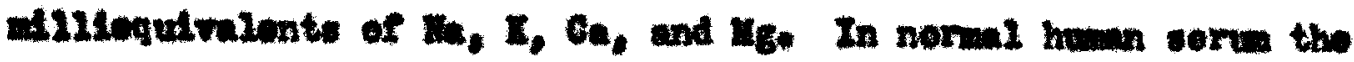




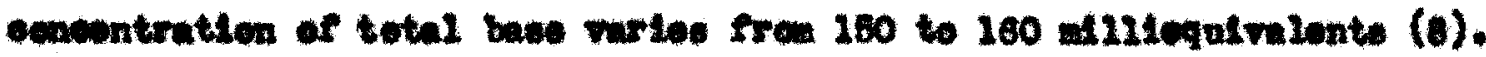

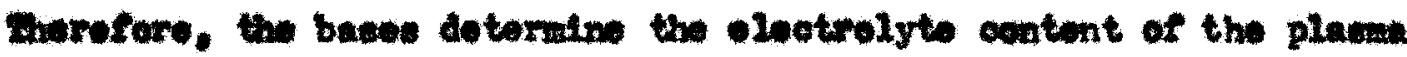
and any obung in the anion content If at the expenes of one or wore of

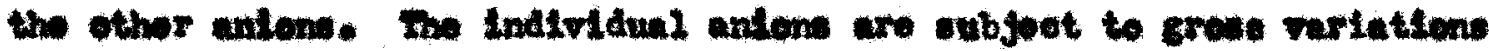

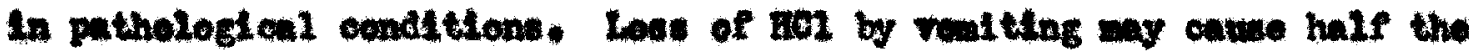

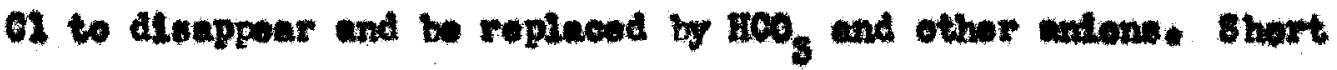
Vigorous correles any ropleos half the bloarbenate with inotate. In-

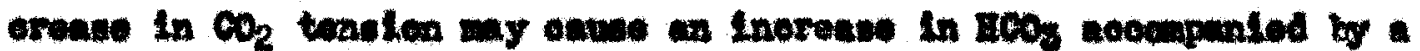

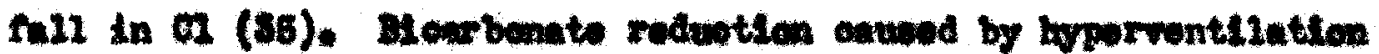
my balansed by tnorease in ci or erganlo sold antene (0). Organto

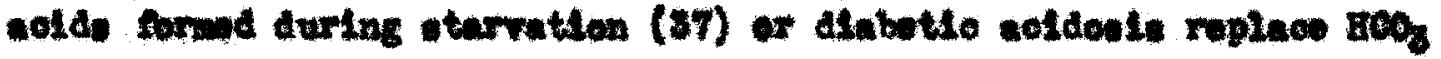
and $\mathrm{an}(20)$. Intimately, if the motabelic onve of the eleotrolyte

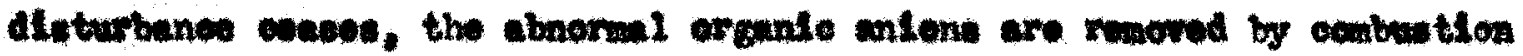

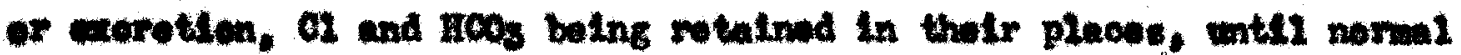
1ento ocapesition of the body fluids in restublishod. rovis anod-

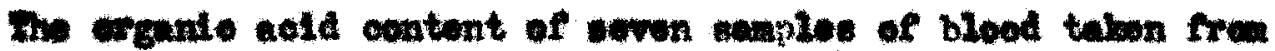

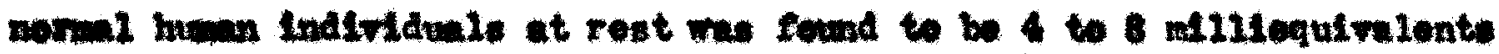
per liter of blood (xuble 6). Only one of the enven Indlviduals had an

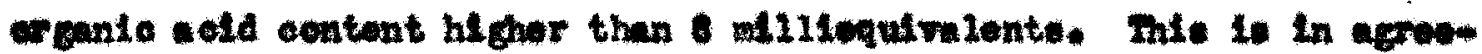

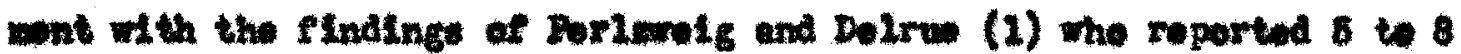
allisquivilente.

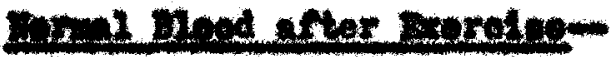

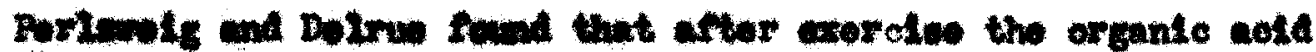

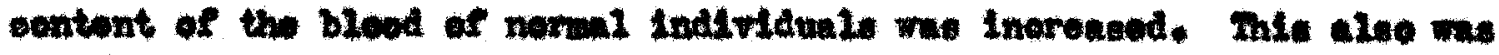

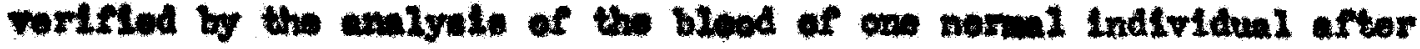

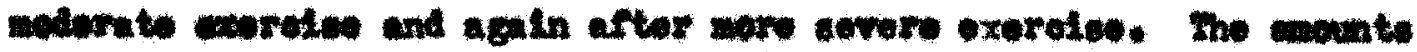




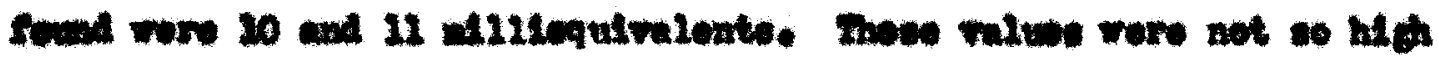

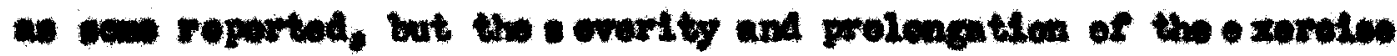

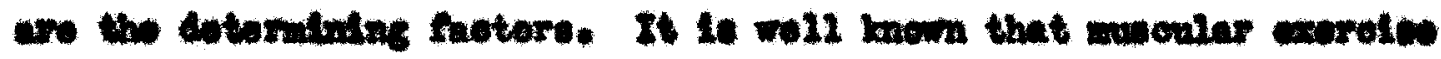

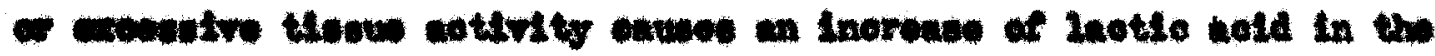

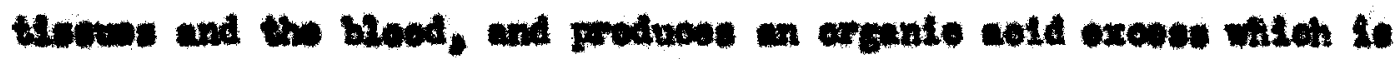

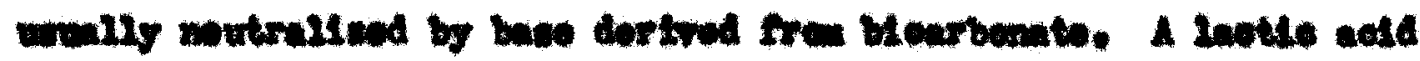

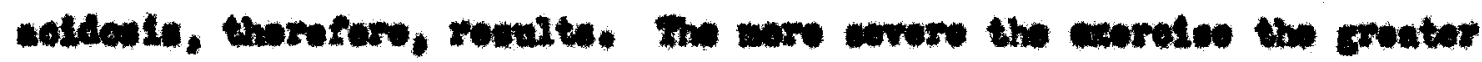

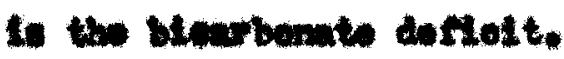

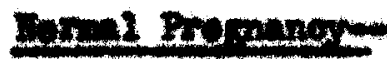

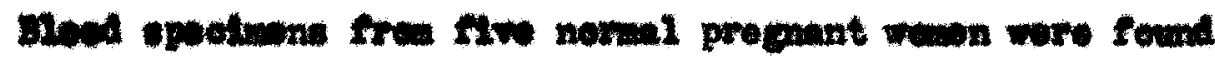

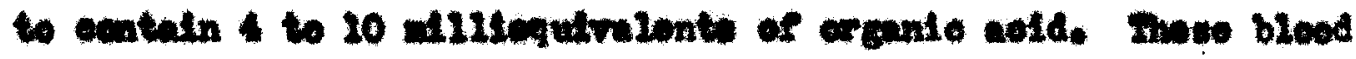

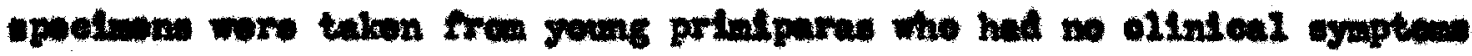

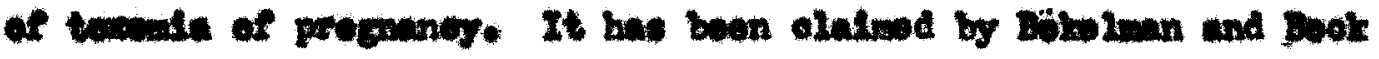

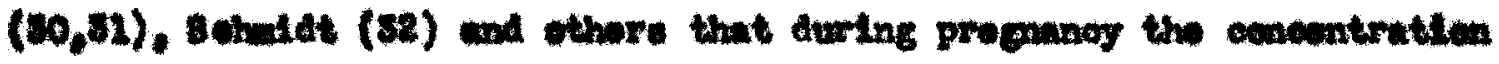

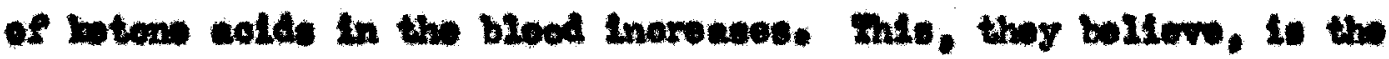

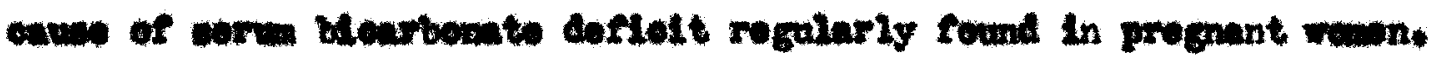

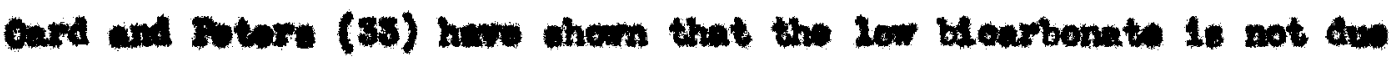

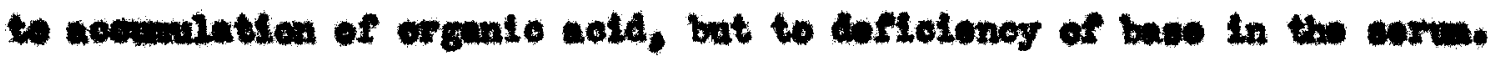

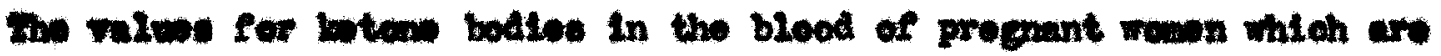

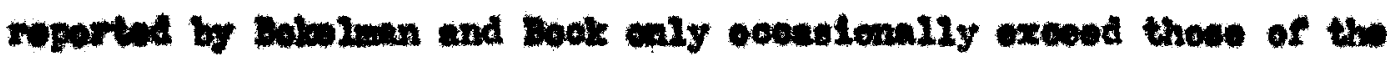

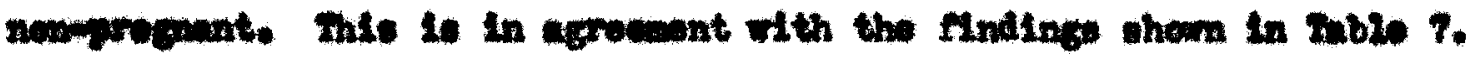

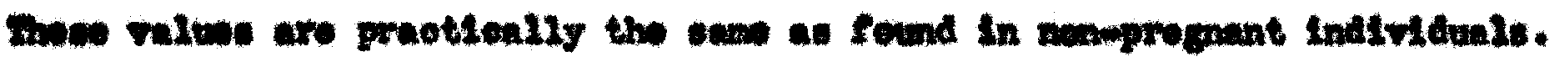

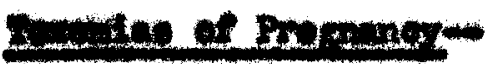

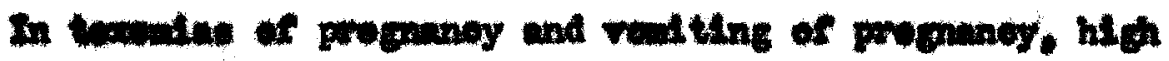

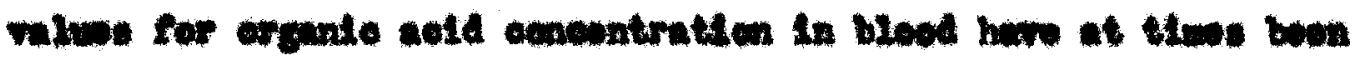

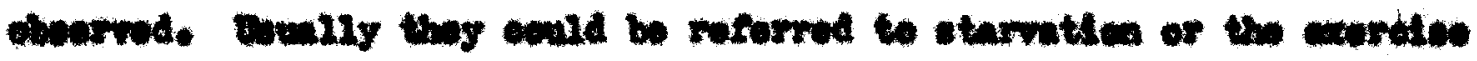

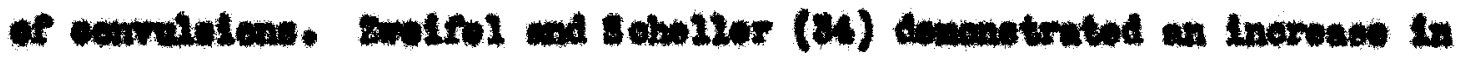




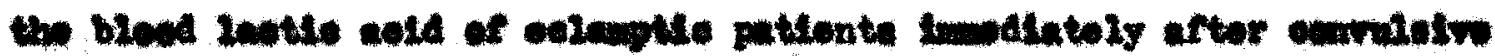

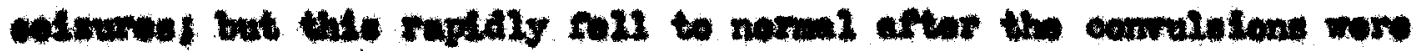
mer.

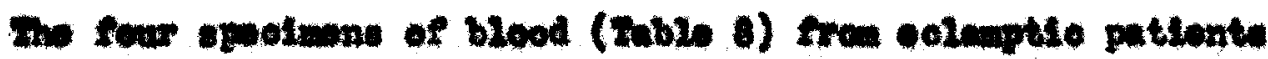

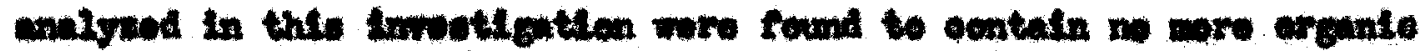

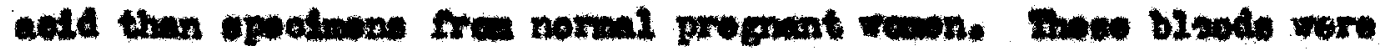

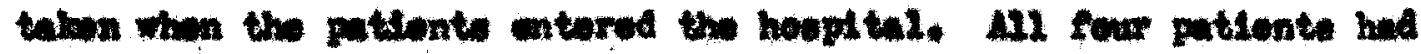

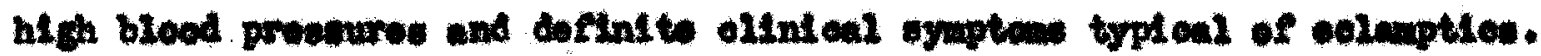

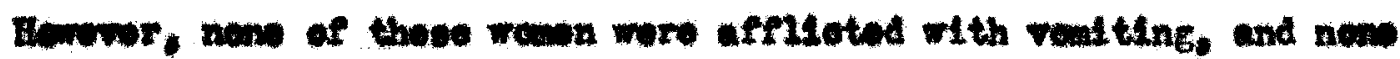
reached the etate of comrulelese, whieh, In the 21 ght of provilew work,

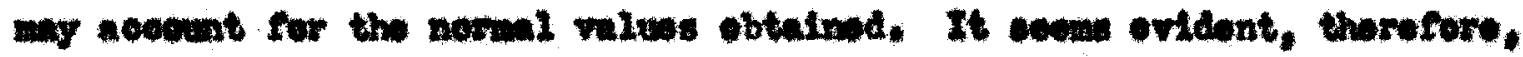
that it if aly In the advanged etages of colmapela that Inorwased ow-

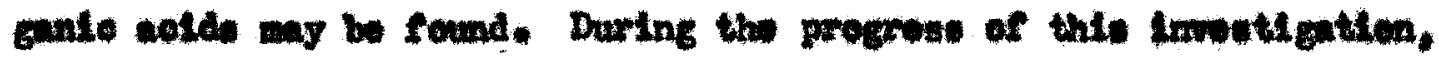

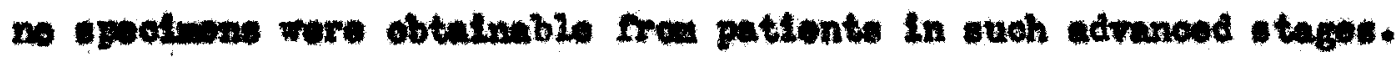

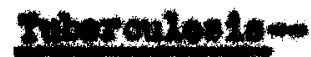

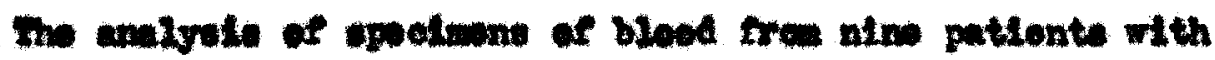

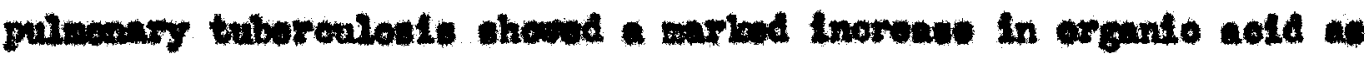

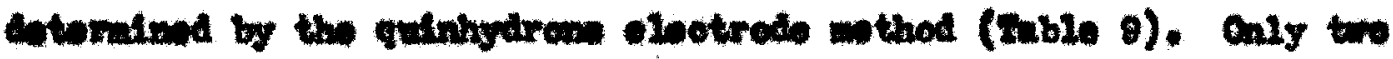

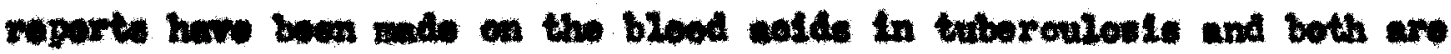

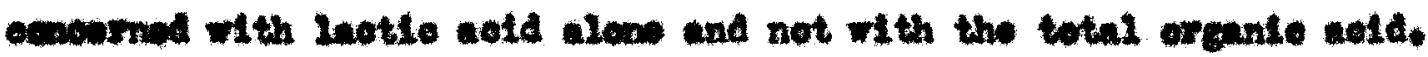

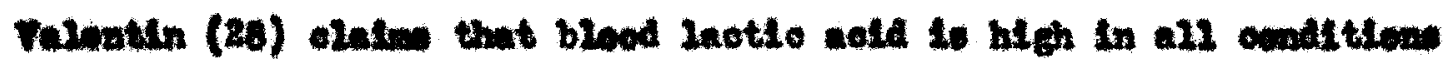

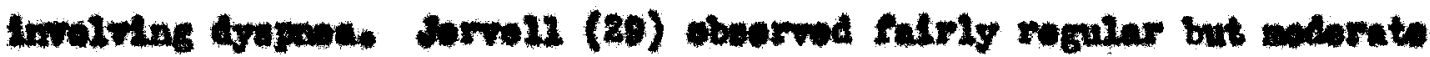

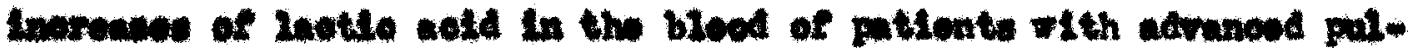

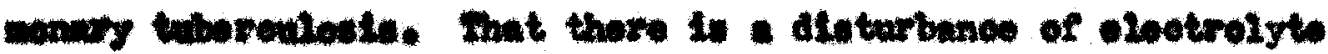

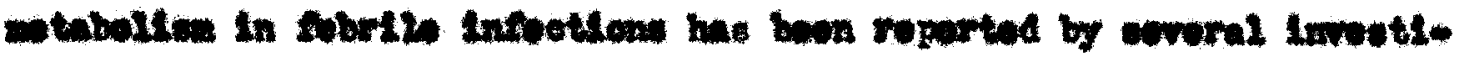

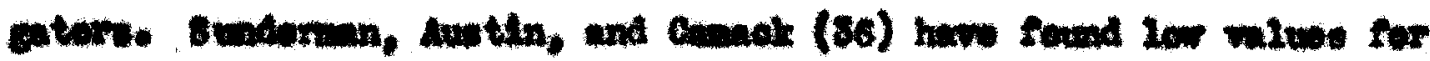

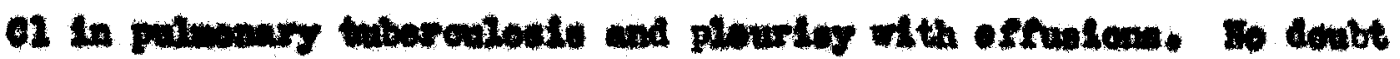




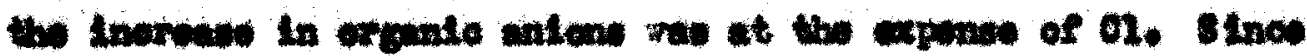

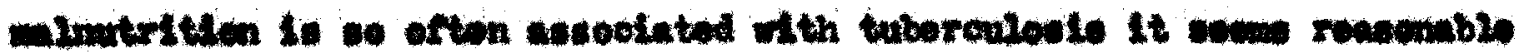

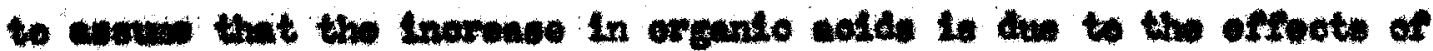

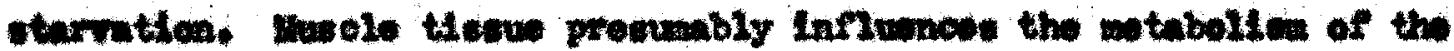

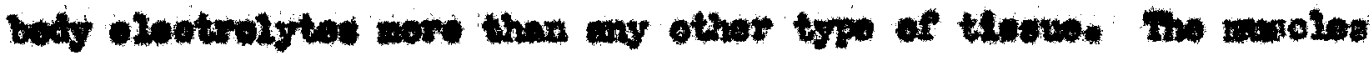

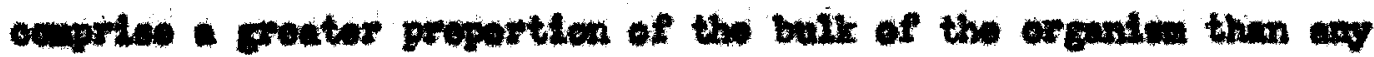

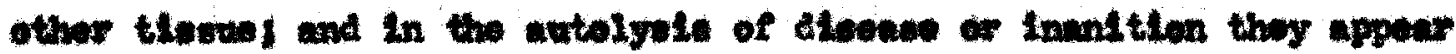
to invelved firet and nost depply.

\section{Dinbees nutro-}

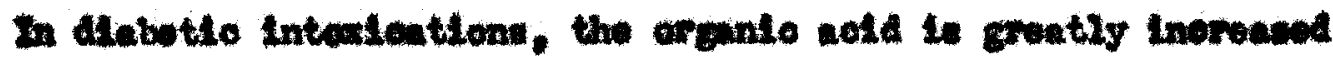

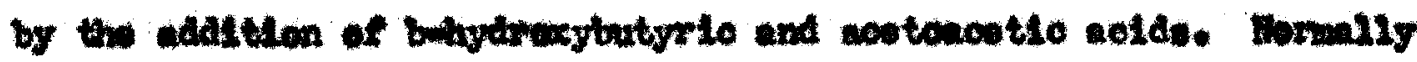

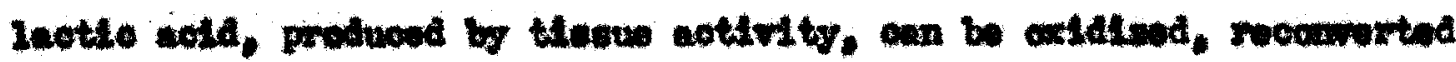

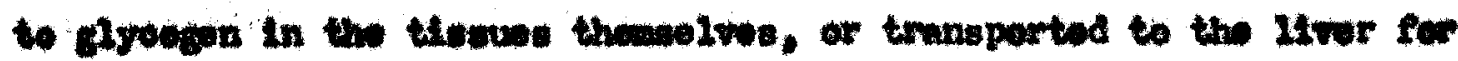

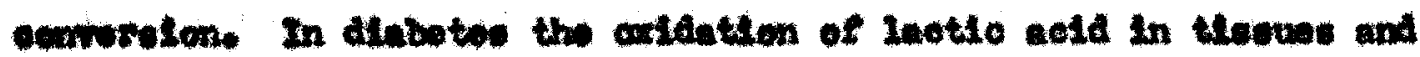

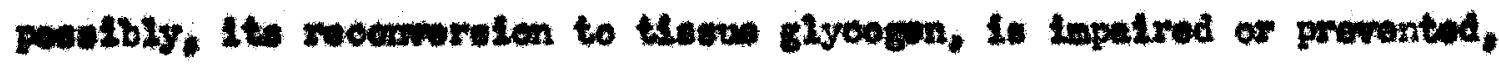

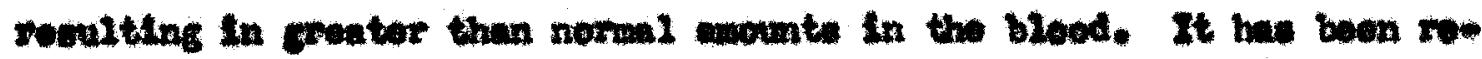

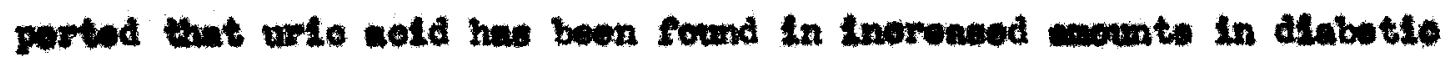

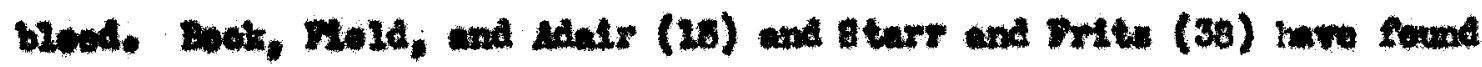

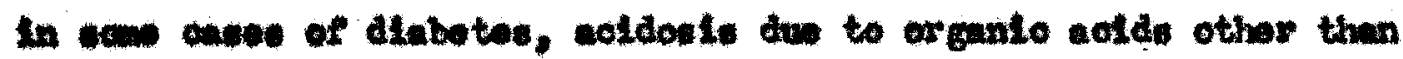

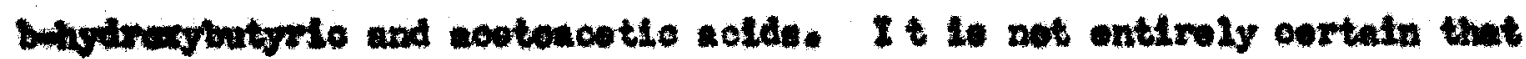
this we roleted direotly to the diabetilo cendilion, although Lablo, Heth

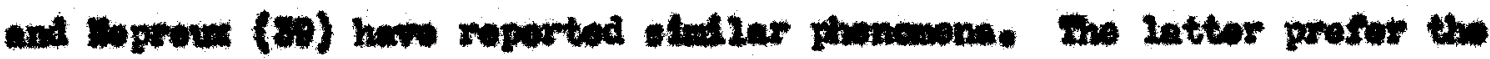

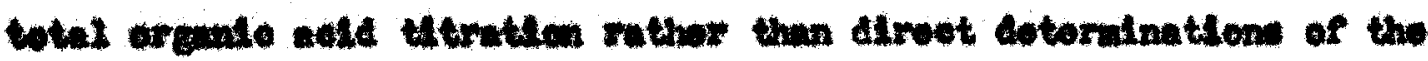

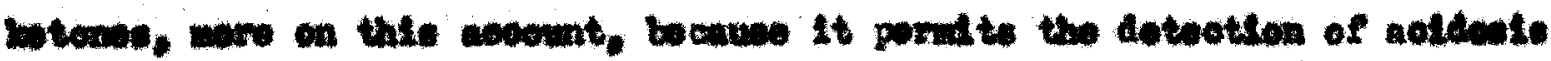

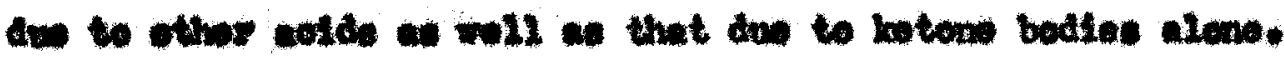

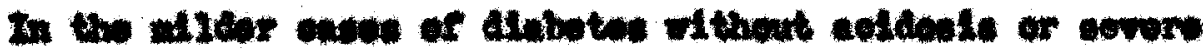

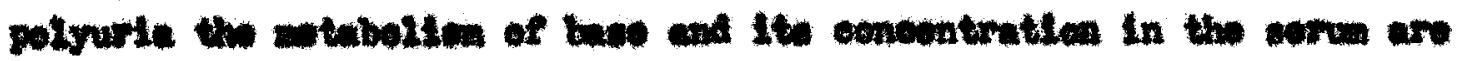


not approclably alsturbod.(10) In covaro diabetio aesdesle it is net

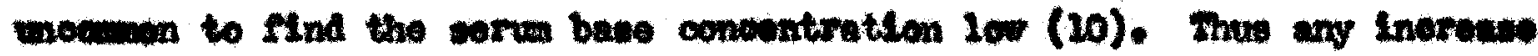

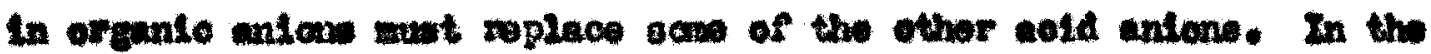

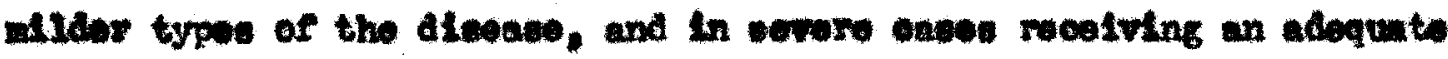

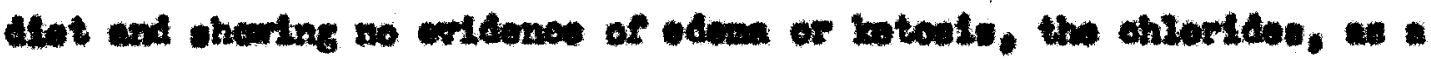

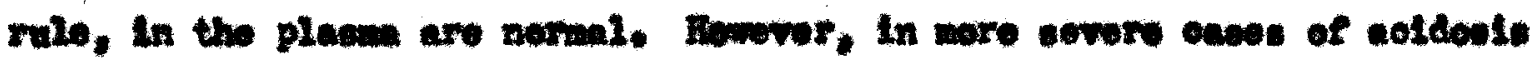

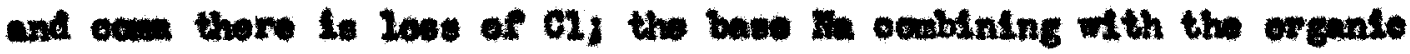

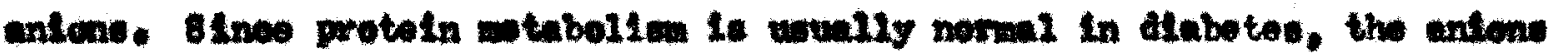

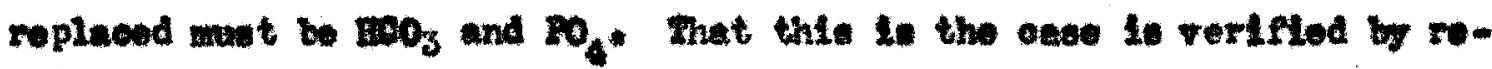

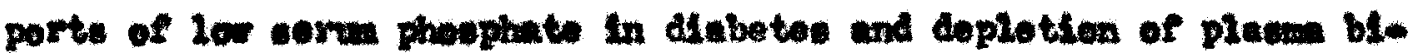

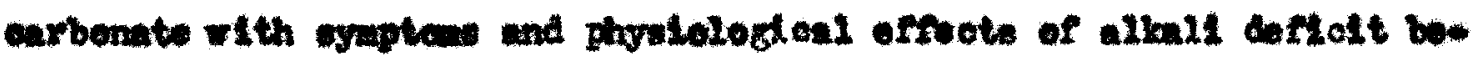
oealing apparont.

In rables 10 and 11 are shew the result of the amalyats of bleods from flfteen difforent humane with diabetes wollitus, mo bleod coger deterninations wore and in the Loulovilie C1ty Benpltal Imberntary.

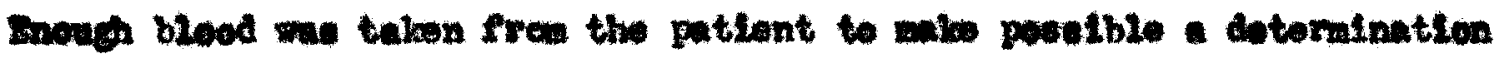

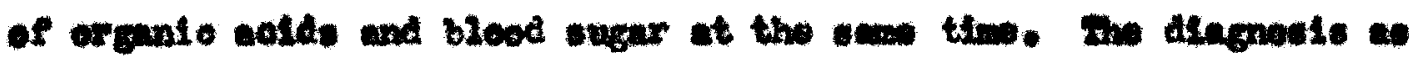
Indicuted in the tablos was taken from the patsent's hopttal ohart. MI but three of the patiente had been reesining or were rocelving in culle during the coverse of the exporiment.

Twe dete ohere that thore is no dafinte relation botmoen

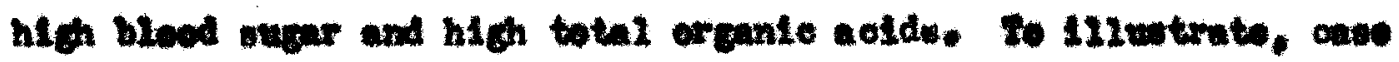
W. B. with en organic ald content of is willequivalents and a bleod

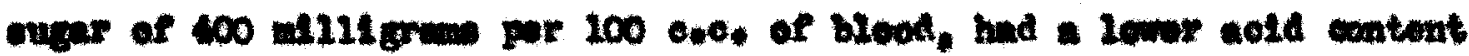

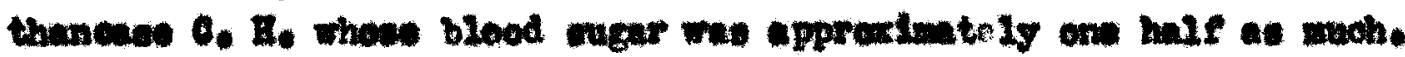

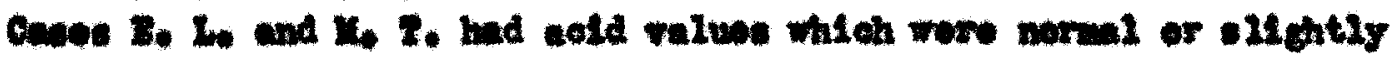

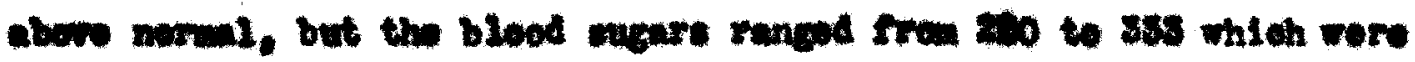




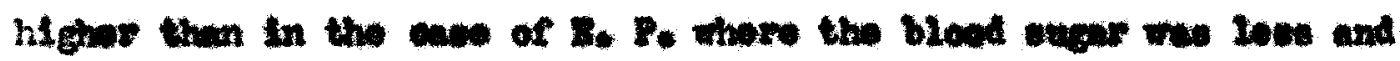

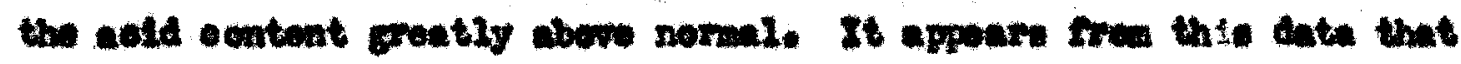
the o entroiling fuotor in Inawin.

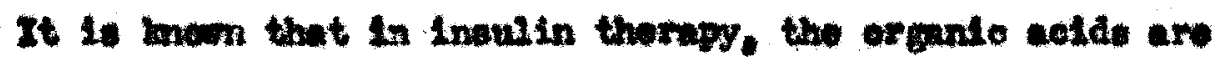

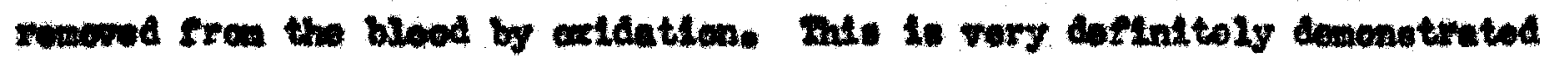

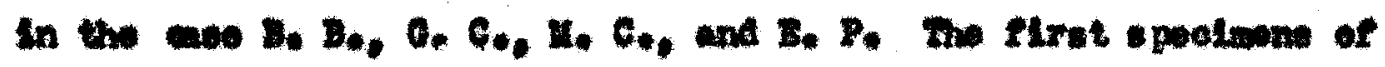

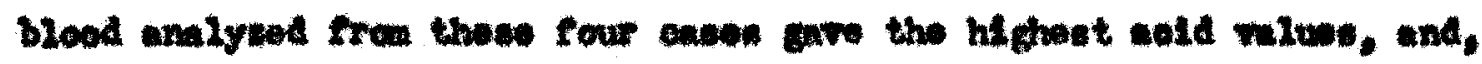

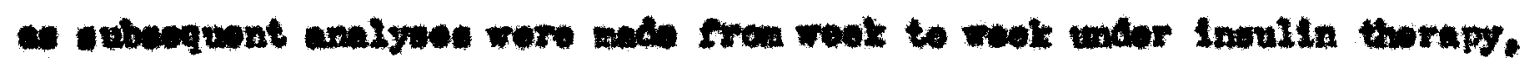

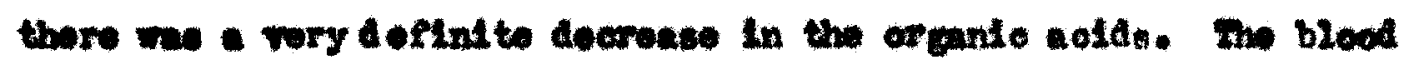

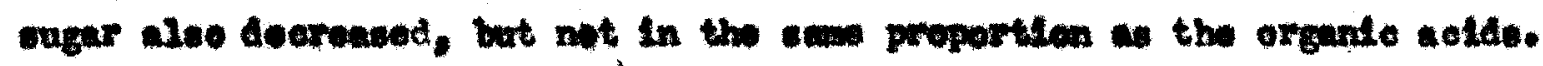

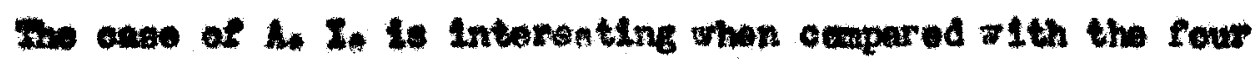

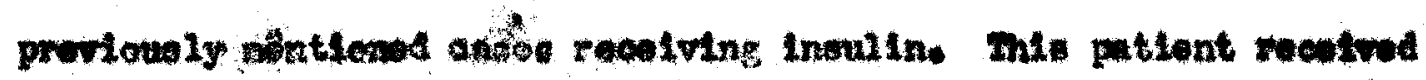

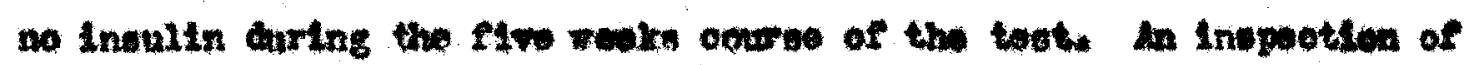

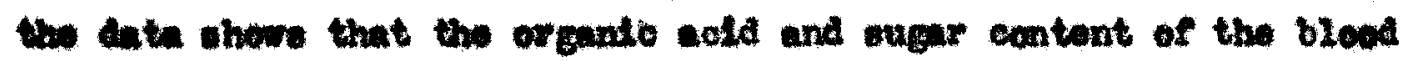
rowalnd umest ooxatant, oven shoring highor wluv for exch ot the

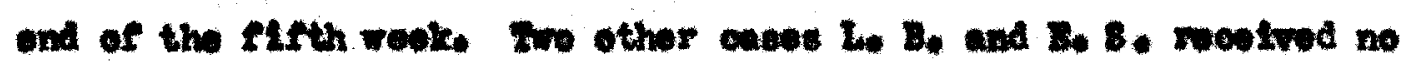
Invulin in troatuent end, shile their blood sugars wero not we 162 and thotr cases wre dlagnosed alld diabetos, yot the bleod organio

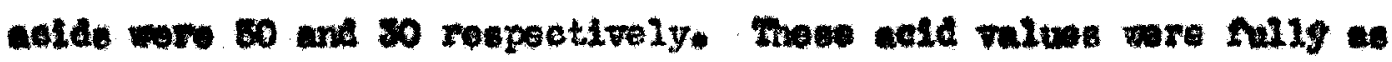

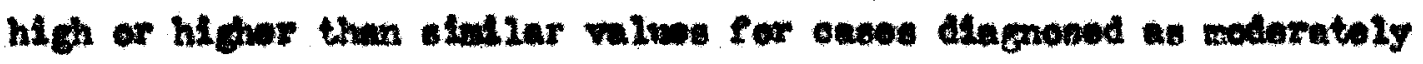

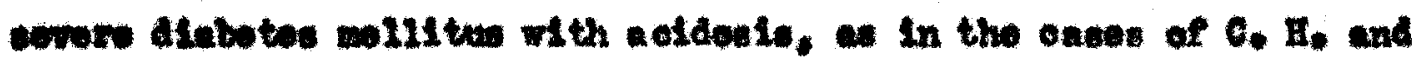
4. I. It rowle evem that the offeot of Ineviln therapy in ronoving

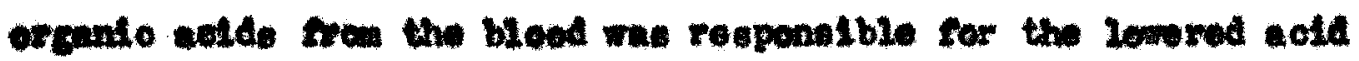
ralve own though the bleod ougar mivoe renatrod high. 
gevara 


\section{senuma}

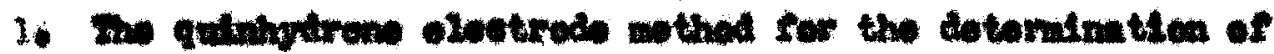

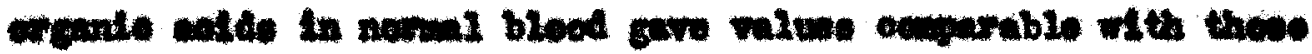

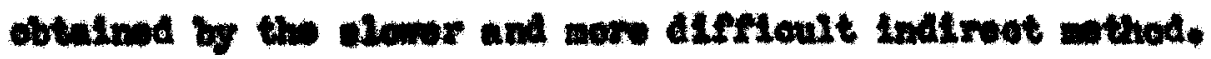

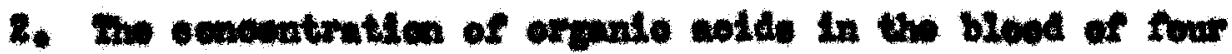

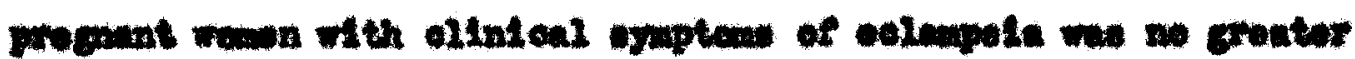

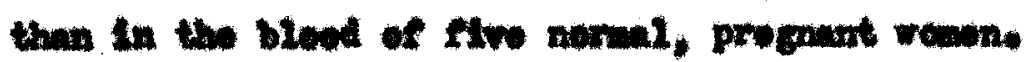

3. To wrente cold ontent of blood frem nim indind duals fith

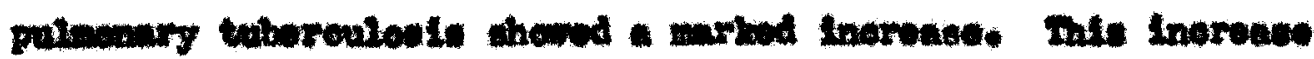

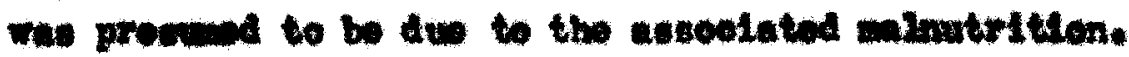

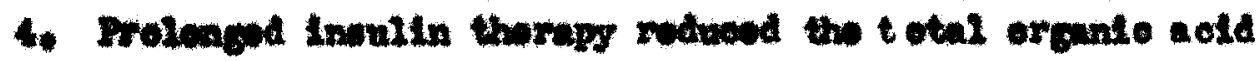
wentent of bived in alsbotos molltwe.

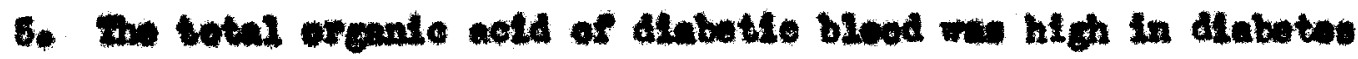

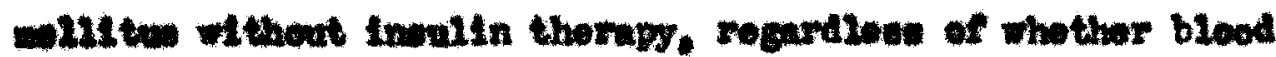

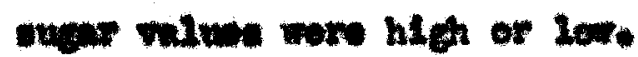


gtanocanir 


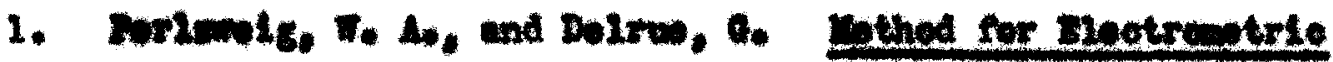

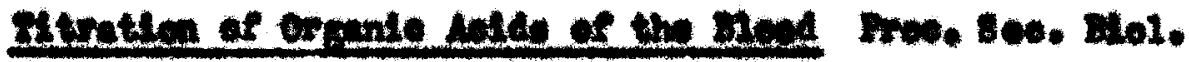
Nid, 1028, 25 .

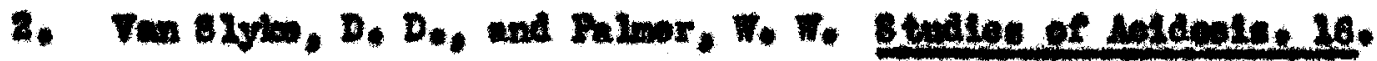

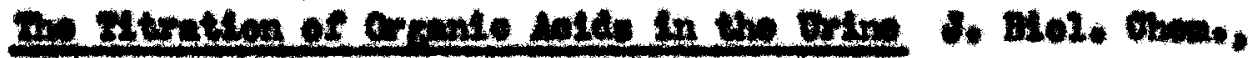
1920, 4, 867 .

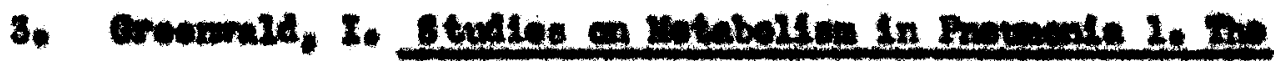

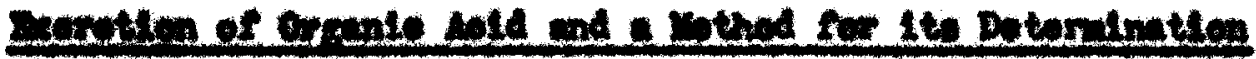
J. Btel. Ohem, 1010, 28, 497.

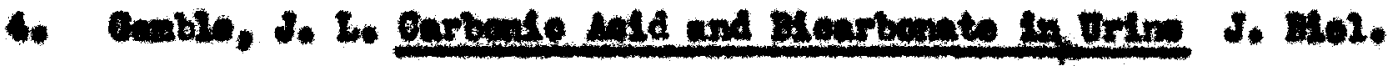
chem. 1928, 2, 205.

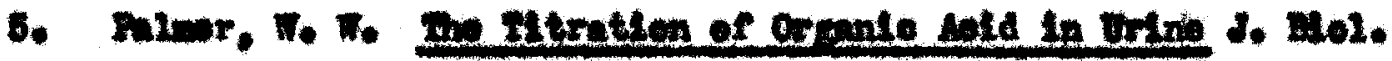
now. 2026, $0,248$.

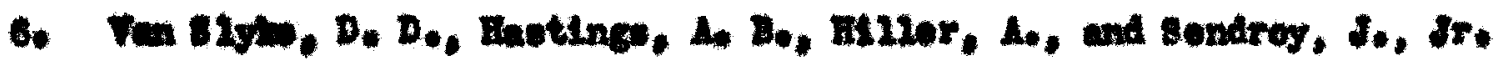

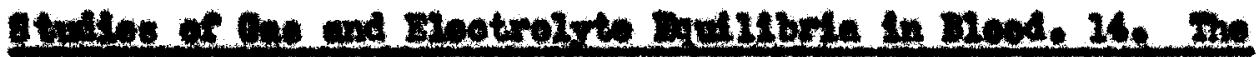

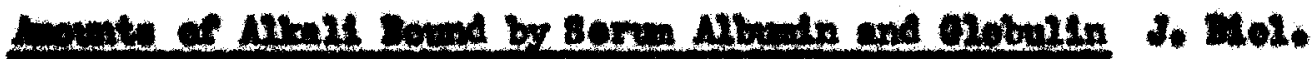
Onime., 1988, D. 700 .

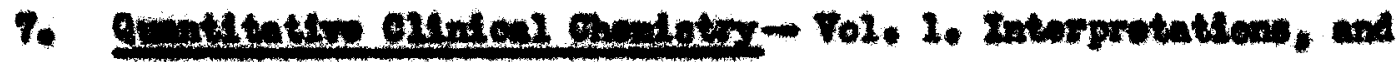

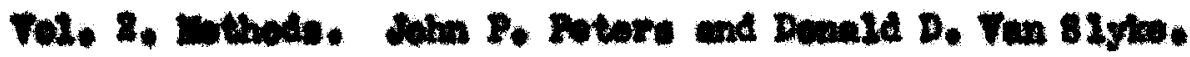

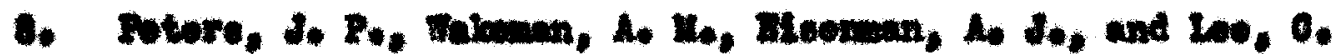

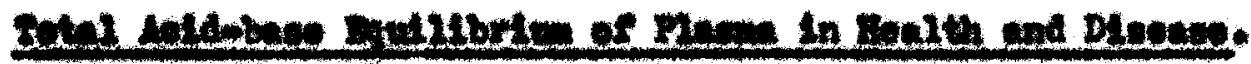

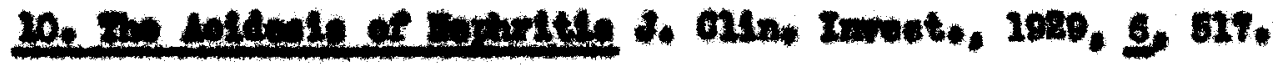




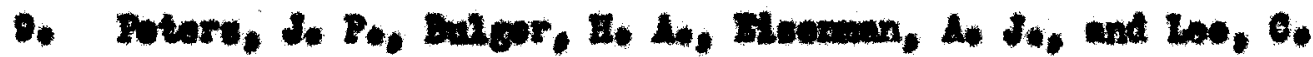

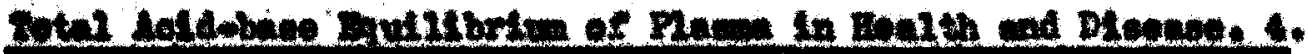

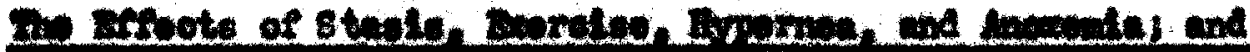

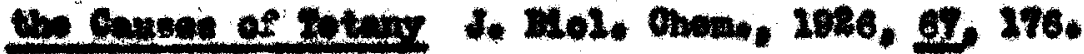

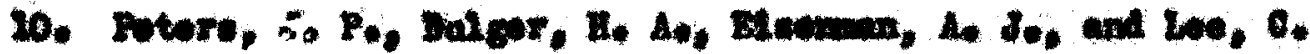

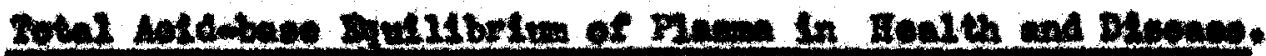

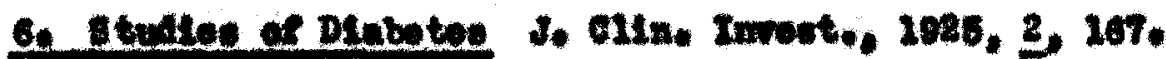

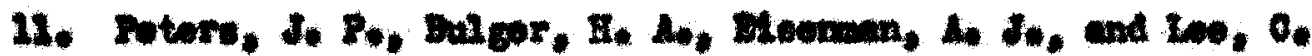

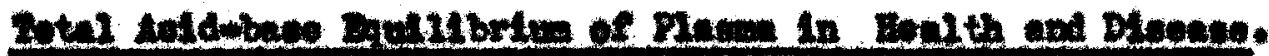

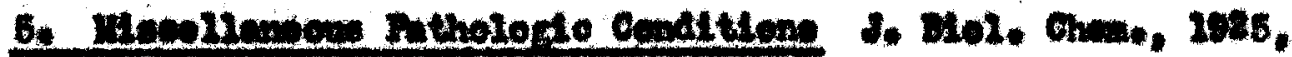
a. 210.

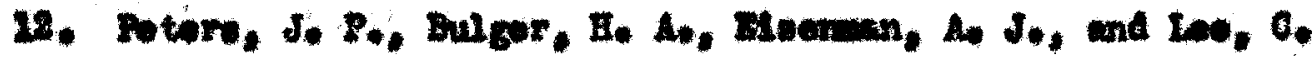

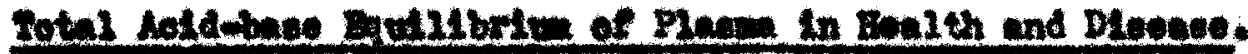

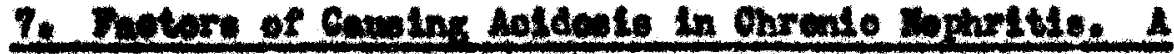

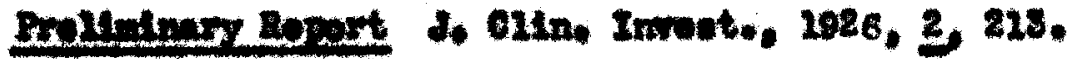

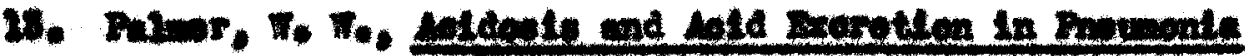
d. Exp, nod, 2017, 26, 400 .

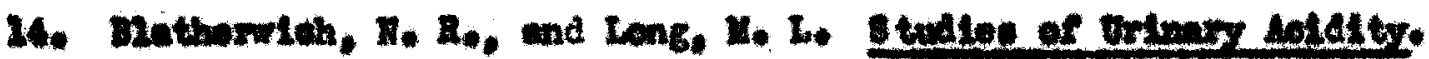

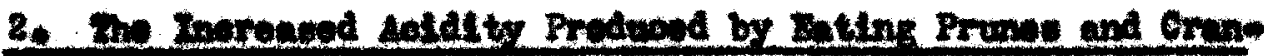

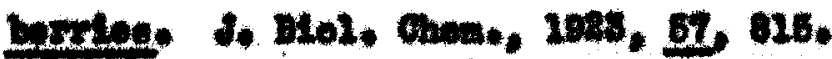

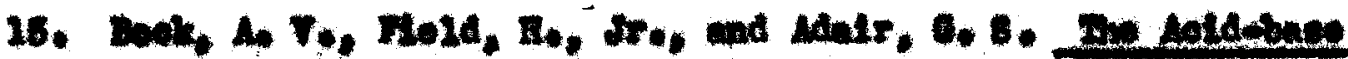

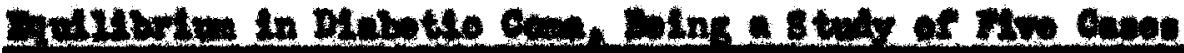

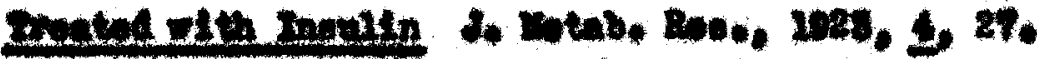




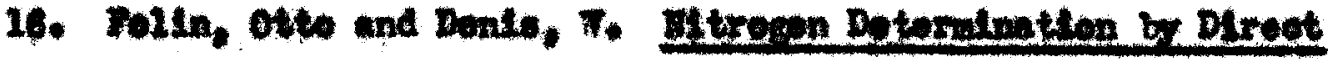

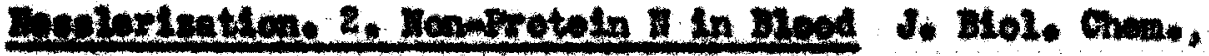
1916, 26, 491.

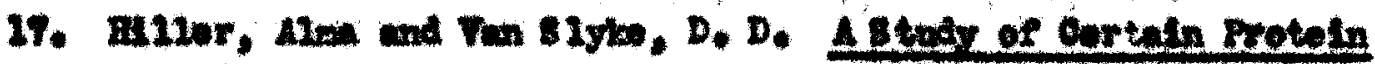

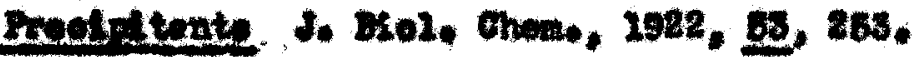

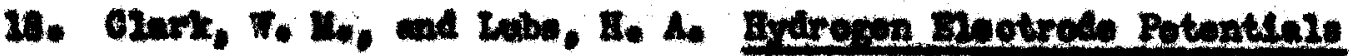

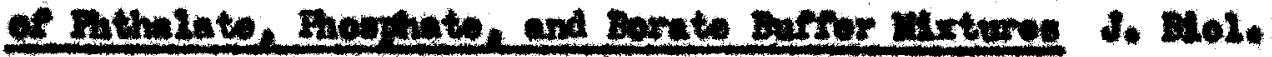
Ohm, 1916, 28, 479.

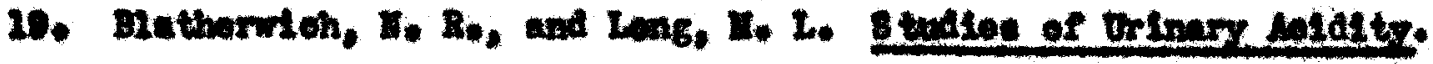

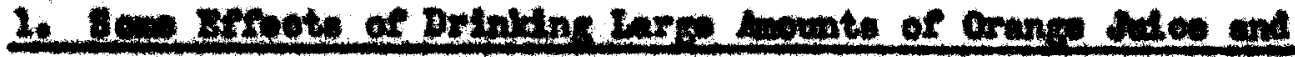

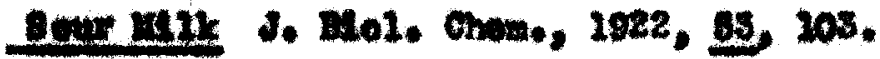

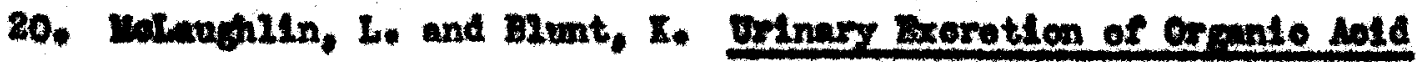

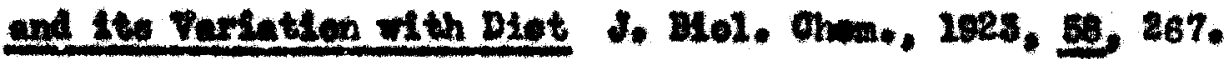

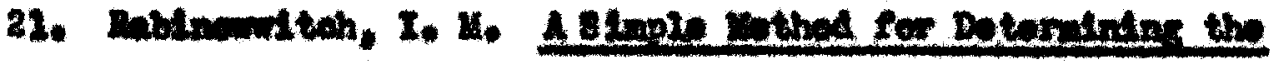

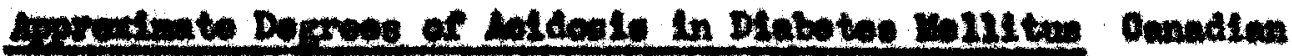

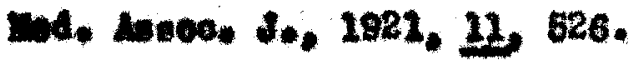

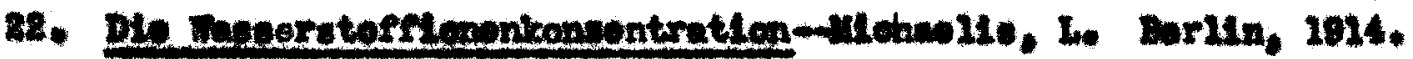

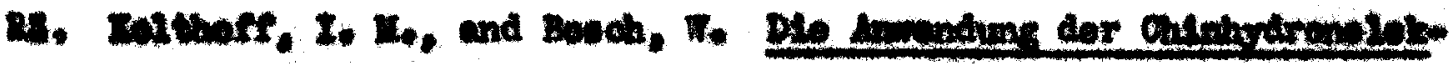

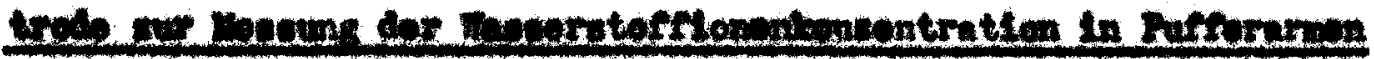

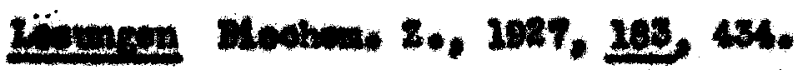

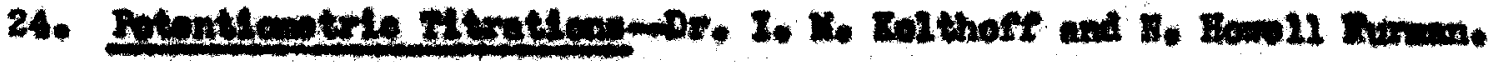

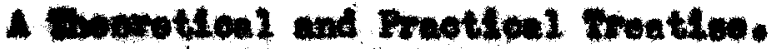




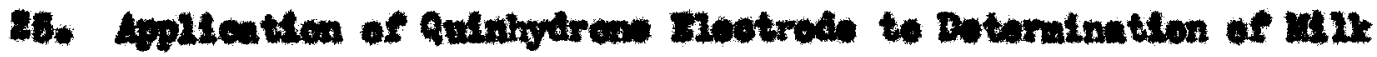

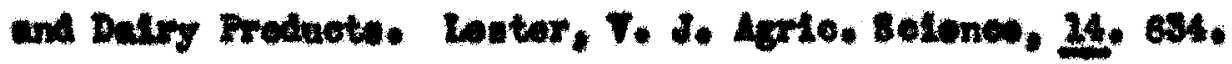

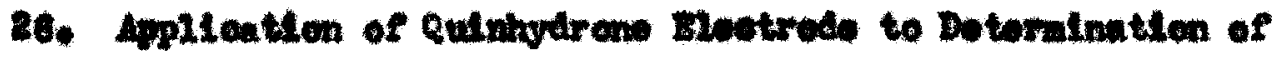

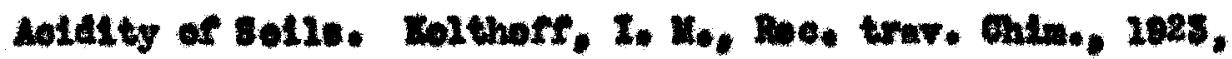

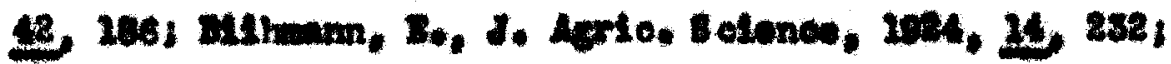

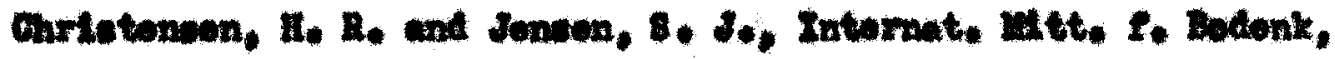
14, nnet2 2, 1924 .

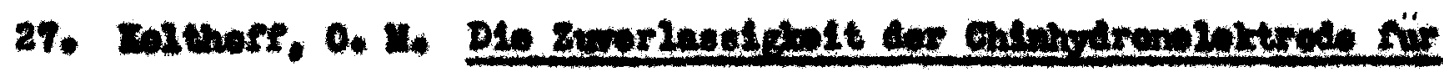

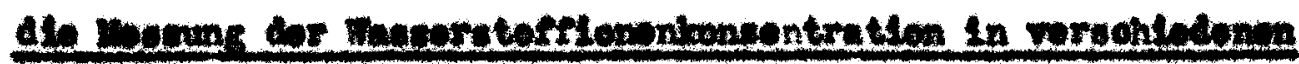

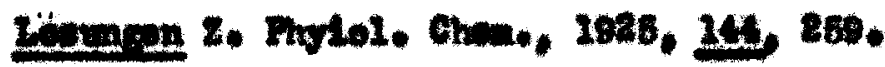

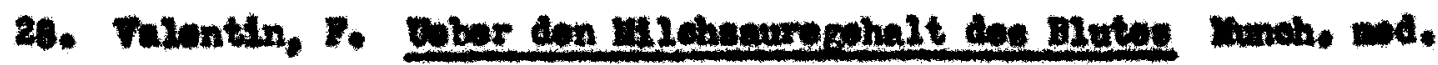
wothe, 1026, $2,86$.

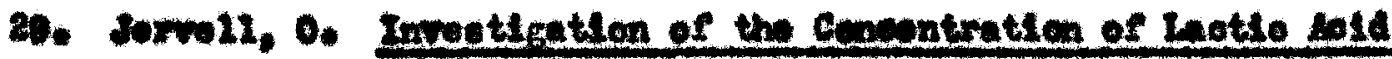

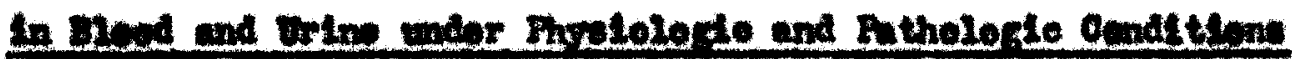
Iotu lud, Boand, 1828, suppl, 24, p. 1.

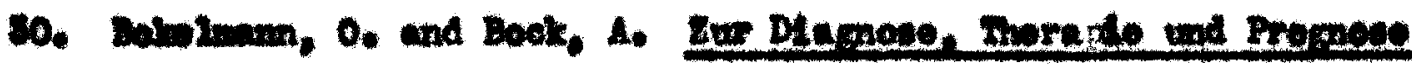

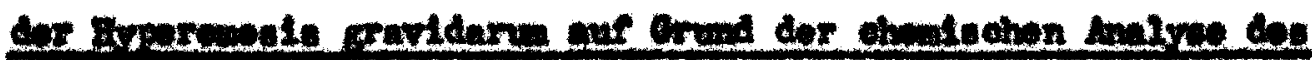

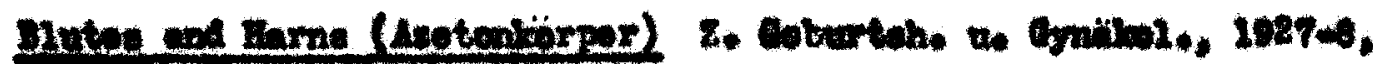
2. 196.

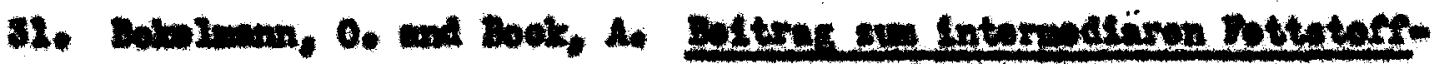

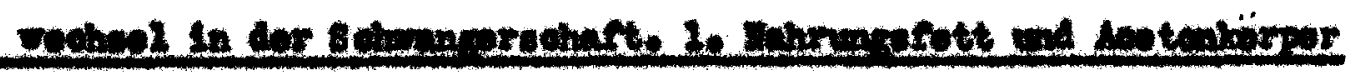

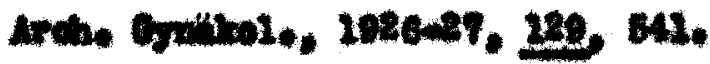




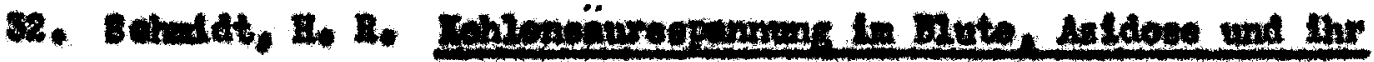

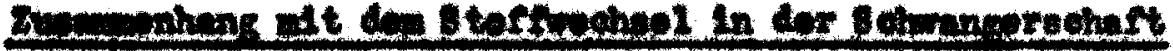

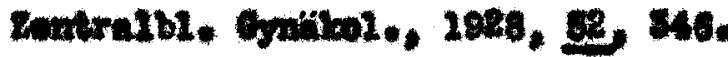

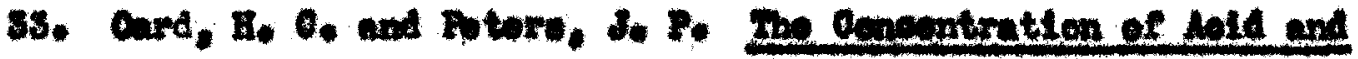

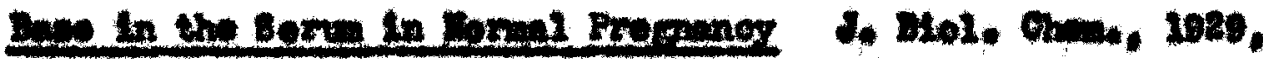
2.8.

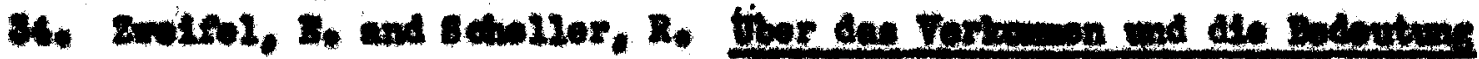

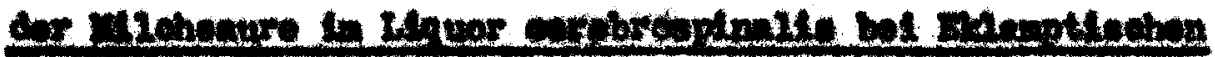

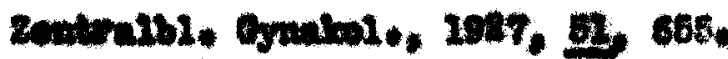

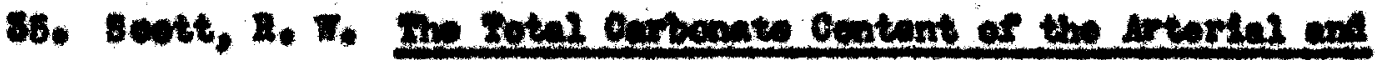

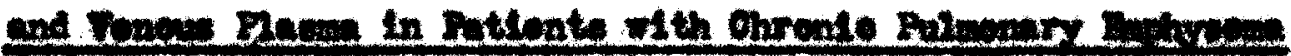

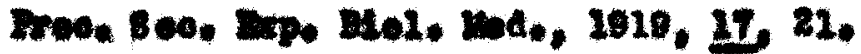

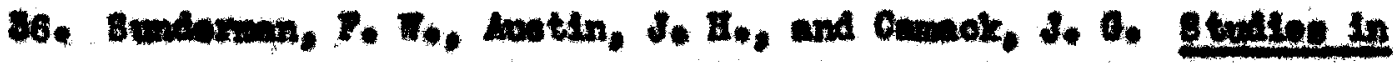

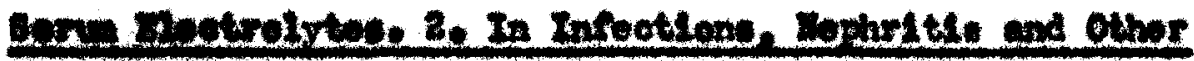

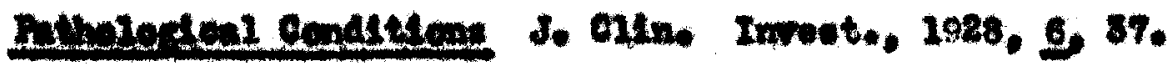

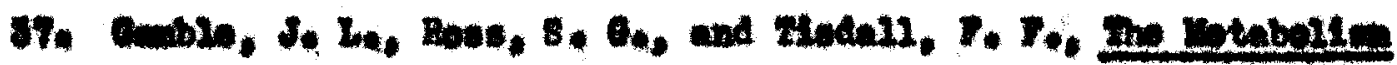

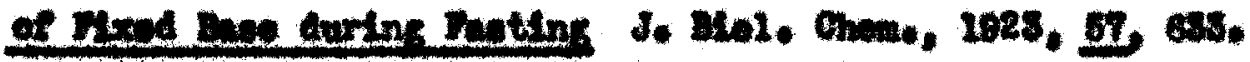

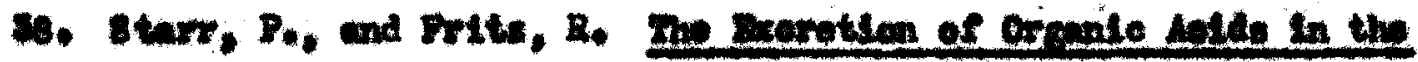

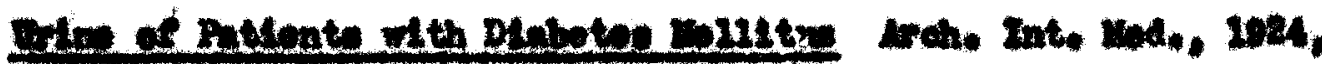
3. 97.

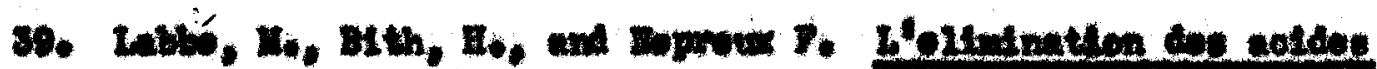

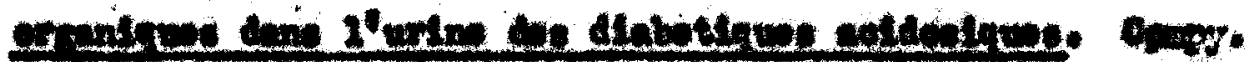

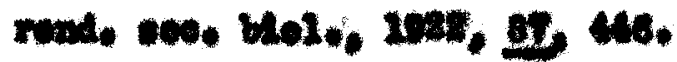




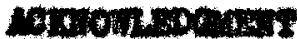

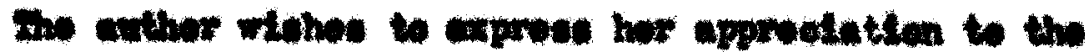

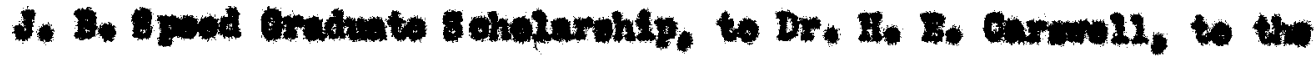

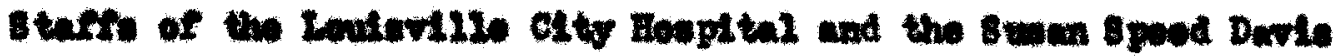

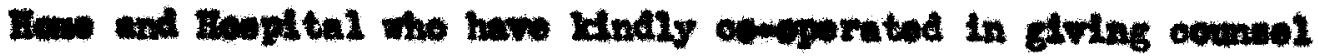

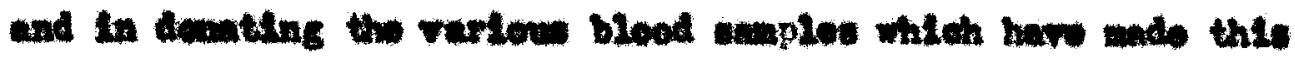
pegearch pocatble. 